\title{
Does the Impact of Board Independence on Large Bank Risks Change After the Global Financial Crisis?
}

\author{
Francesco Vallascas, Sabur Mollah, and Kevin Keasey ${ }^{*}, \dagger$
}

\section{Journal of Corporate Finance, Forthcoming.}

\begin{abstract}
The view that the independent directors of large banks should contribute to safeguarding the interests of bank creditors and taxpayers, by exercising a stringent risk oversight of bank executives, has gained ground in the aftermath of the 2007-2009 crisis. Using a cross-country sample of large banks for the period 20042014, we show that post 2009 an increase in board independence leads to more prudent bank risk-taking compared to the rest of the sample period. This effect materializes via independent boards favoring increases in bank capitalization and decreases in bank portfolio risk after the global crisis. Additional analyses demonstrate, however, that these results do not hold for all large banks in our sample but are confined to the group of banks benefiting from a government bailout during the crisis. In most large international banks board independence does not contribute to safeguarding the interests of bank creditors and taxpayers by constraining bank risk-taking.
\end{abstract}

JEL classification: G21, G28.

Keywords: Bank Risk, Bank Governance, Board Independence, Regulation.

\footnotetext{
* Please address all correspondence to Francesco Vallascas, Leeds University Business School, Maurice Keyworth Building, The University of Leeds, LS2 9JT, UK. Phone: +44(0)1133434483; Fax: 44 (0)113 343 4459; e-mail: fv@lubs.leeds.ac.uk. Kevin Keasey is at Leeds University Business School, The University of Leeds, UK; e-mail: kk@lubs.leeds.ac.uk. Phone: 44 (0)113 343 2618. Sabur Mollah is at the Hull University Business School, University of Hull, UK; e-mail: S.Mollah@hull.ac.uk; Phone: +44 (0)1482 463244. + We acknowledge the financial support from Jan Wallenders and Tom Hedelius Stiftelse, Handelsbanken, Sweden (Project ID P2010-0144:1). We thank participants at the Work and Happiness Seminar Series (WHSS) at the School Business School, Stockholm University, Fredrik Nilsson and other participants at the Uppsala University Business School Seminar Series, Mats Wilhelmsson, Cecilia Hermansson and other seminar participants at the Centre of Banking and Finance, Royal Institute of Technology (KTH), Louis Nguyen and other participants at the FMA International European conference June 2014, Phyllis Keys and other participants at FMA International Annual Meeting October 2014 for their helpful comments and suggestions. We are grateful to Andreea Bordianu, Shakwat Hossain, Sharifur Rahman, and Omar Sikder for their helpful research assistance.
} 


\section{Introduction}

In this paper we examine whether the impact of board independence on the risk-taking of large banks changes after the 2007-2009 global crisis. We base our analysis on a unique international sample of 262 large banks, selected for the period $2004-2014$.

The instability of banks during the global crisis and the related widespread losses produced by the banking industry highlight the negative externalities that can be generated by bank excessive risk-taking, especially when banks are large (Zhang et al., 2015). It is widely believed that these externalities are also the result of ineffective monitoring mechanisms stemming from bank internal governance (Adams, 2012; Beltratti and Stulz, 2012; Erkens et al., 2012; Minton et al., 2014; OECD, 2010). Along these lines, the literature offers a particularly critical view of how independent directors monitored and advised bank executives before the global crisis (Adams, 2012; Anginer et al., 2016; Erkens et al., 2012; Minton et al., 2014). In spite of this critical view, there is still an expressed belief in a number of policy reports and initiatives that large banks benefit from maintaining highly independent boards post the global crisis (Basel Committee on Banking Supervision 2010; 2015). The consequent assumption is that independent directors should behave differently post the crisis thus becoming important to avoid bank excessive risk-taking.

Understanding whether internal governance mechanisms, such as board independence, become effective in mitigating large bank risk-taking post the crisis is an important policy issue. Better functioning internal governance mechanisms would reduce the need for costly prudential regulatory interventions aimed at constraining bank risk-taking. The consequent regulatory response post the global crisis in the form of more stringent prudential requirements, in particular for large and systemically important banks, would then be less necessary.

The literature focusing on the career concerns of independent directors and the market for directors offers a few reasons as to why the independent directors of large banks might be more effective in limiting excessive risk-taking post the global crisis (Jagannathan et al., 2015; Jiang et al., 2015). Independent directors aim to maintain a good reputation in the directorship market as this will help gain additional board seats in the labor market going forward (Fama and Jensen, 1983; Ferris et al., 2004; Jagannathan et al., 2015; 
Yermack, 2004). In addition, reputational incentives are more relevant when directors sit on the boards of large corporations and these incentives amplify the directors' efforts in the execution of their duties (see Masulis and Mobbs, 2014; 2016). In general, directors seen as negligent in performing their role are penalized by the directorship market (Fich and Shivdasani, 2007; Gilson, 1990; Harford, 2003).

The assessment of the performance of independent directors, however, critically depends on what the market (and regulators in the case of banks) expects from them and, consequently, which objectives the directors should help a corporation to achieve. In this respect, the post-crisis perspective, as rooted in a number of regulatory guidelines and initiates (see Basel Committee on Banking Supervision, 2010; European Union 2010) and echoing the view of numerous academics and policy makers (Becht et al., 2012; Berger et al., 2014; Bolton et al., 2015), indicate that bank boards should favor a stakeholder approach. Bank independent directors should then contribute to balancing the different objectives of a wider set of stakeholders, including creditors and taxpayers, and not only focus on shareholder interests.

Further, the growing emphasis on the stakeholder perspective is accompanied by regulators and supervisors explicitly requiring that independent directors facilitate a more accurate and stringent riskoversight post the crisis (see, for instance, the Dodd-Frank Act (July 2010) in the US and the EU Capital Requirements Directives (approved in 2013) in Europe). In summary, post the global crisis the general drive for bank boards has been to search for independent directors with the skills and knowledge to enable a more stringent risk-oversight of bank executives and to exercise this oversight taking into account the interests of the wider group of bank stakeholders. These changes have then the potential to influence the demand and supply of directors' services in the labor market.

To evaluate whether the changing landscape post the global crisis affects the relationship between board independence and bank risk, we construct our analysis in a panel data setting that relates accounting and market based measures of banking risk to the degree of board independence and its interaction with a dummy variable that identifies the post-crisis period. Following previous studies, we employ a bank's ZScore as an accounting measure of risk (Beck et al., 2013; Boyd et al., 2006; Boyd and Runkle, 1993), and 
bank volatility (Patham, 2009) and tail risk (Ellul and Yerramilli 2013; Van Bekkum, 2016) as market measures of risk-taking.

Our initial tests show that post the crisis an increase in board independence leads to more prudent bank risk-taking compared to the rest of the sample period. This result is confirmed for all the different risk measures we employ in our analysis and under different econometric methods. To further confirm that our results are not spurious we next focus on the impact of board independence on the components of a bank's Z-Score; namely, ROA, the Equity Ratio and ROA Volatility. We conjecture that we should observe that i) the impact of board independence on at least some of these variables differs post 2009 (compared to the rest of the sample period) and ii) the observed differential impact should be consistent with an enhanced risk-decreasing effect of board independence on bank insolvency risk post 2009. In line with our conjecture, we demonstrate that the risk-mitigating effect observed post 2009 is accompanied by independent boards favoring increases in bank capitalization and decreases in bank ROA volatility.

While these initial results apparently validate the regulatory perspective on the importance of board independence in banks, they are still insufficient to indicate a generalized shift in the impact of board independence on bank risk post the crisis. In particular, some of the banks in our sample have produced significantly larger damages for creditors and taxpayers, and consequently placed larger costs on public finances, in the aftermath of the global crisis. As a result, these banks have been subject to heavier regulatory and media scrutiny with the consequence of being more likely affected in the composition of their boards and on how independent directors interpret their role post-crisis. Our results might then be driven by independent directors sitting on the boards of bailout banks that are exercising a more stringent risk oversight to comply with wider stakeholder objectives post-bailout.

Our analysis proceeds, therefore, by exploring how our main findings vary amongst banks that have received a government bailout during the global crisis and the remaining banks in our sample. We start by initially examining the impact of board independence (measured at the end of 2006) on the likelihood to receive government support and on the amount of public funds per unit of bank assets that a bank has required to restore its capital strength. We find that banks with more independent boards before the crisis 
tend to have a larger bailout probability and to extract significantly larger amounts of public funds (at the expense of taxpayers). This conclusion holds under different specifications and for the sub-sample of US banks and motivates concerns over the monitoring role of independent directors before the crisis especially if sitting on the boards of bailout banks.

We then show that our findings for the post-global crisis period of a changing impact of board independence on bank risk are indeed driven by the independent directors sitting on the boards of bailout banks post the crisis. We confirm this result under different empirical settings and when we focus on the sub-sample of US banks. For the remaining large banks, independent directors remain ineffective as a riskmitigating mechanism in our sample period including the post-crisis period.

Overall, our analysis shows that post the global crisis it is only the independent boards of large banks that have received government support that become significantly more aligned with broader stakeholder objectives and offer more stringent risk oversight. As the independence of large bank boards remain largely an uninfluential driver of risk-taking, the strengthening of the external monitoring of large banks by regulators and supervisors remains pivotal to safeguarding the interests of bank creditors and taxpayers.

Our study contributes to the still limited literature that assesses the nexus between governance and bank risk using a cross-country setting (see, for instance, Laeven and Levine, 2009; Lepetit et al., 2015) and in particular to studies that examine the impact of board characteristics on bank risk and capital (Anginer et al., 2016; Beltratti and Stulz, 2012; Erkens et al., 2012). Our analysis extends and complements these studies by offering novel evidence on the changes in the impact of board independence on bank risk in the years following the crisis.

Our analysis is also related to studies on the drivers of bank bailouts occurring during the global financial crisis (see, for instance, Adams, 2012; Bayazitova and Shivdasani, 2012), and especially to US studies (Berger and Roman 2015; Black and Hazelwood, 2013; Duchin and Sosyura, 2014) and cross-country studies (Brandao-Marques, 2012) that focus on the post-bailout behavior of supported banks. This latter group of analyses examine the bailout implications on competition (Berger and Roman 2015), the lending policy of small and large banks (Black and Hazelwood, 2013), lending risk and loan supply (Duchin and Sosyura, 
2014) and risk-taking by rated banks (Brandao-Marques, 2012). Differently from our analysis, therefore, this group of studies does not focus on the nexus between bank governance and post-bailout behavior.

The rest of this paper proceeds as follows. Section 2 discusses the potential impact of independent directors on the risk behavior of banks and why this impact could be different after the global crisis. Section 3 presents the sample of large banks, and the definition and summary statistics for the key variables. Section 4 discusses the baseline results, while Section 5 controls for differences between bailout and non-bailout banks. Section 6 offers conclusions.

\section{Bank Risk-Taking and the Role of Independent Directors}

As in any corporation, the boards of large banks can influence the risk choices of executives by means of their advisory and monitoring functions (see Adams et al., 2010). A particularly important role in shaping risk choices is normally assigned to independent directors. These directors are conventionally seen as better monitors than other directors as one of their key objectives is to maintain a good reputation in the directorship market (Fama and Jensen, 1983).

Studies on non-financial firms show that career opportunities in the directorship market depend on independent directors achieving good past performance in the execution of their mandate (Coles and Hoi 2003; Farrell and Whidbee 2000; Gilson, 1990; Harford 2003; Jiang et al., 2015). Good past performance has significant reputational effects that increase the chances to gain directorships in the labor market. In contrast, poorly performing directors see a decline in the demand for their services in the labor market and tend to hold fewer directorships (Fich and Shivdasani, 2007; Gilson, 1990; Harford, 2003). Furthermore, reputation concerns also affect the supply of director services in the labor market, with directors that are members of the boards of large corporations increasing their effort in performing their duties (see Masulis and Mobbs, 2014; 2016).

The literature on non-financial firms normally links the notion of good performance by independent directors to the interests of shareholders (Coles et al., 2008; Fama and Jensen, 1983; Hermalin and Weisbach, 2003; Jensen and Meckling, 1976; Wagner, 2011). In the case of large banks, however, what constitutes good performance by independent directors has been called into question by the global financial 
crisis. The crisis is a key example of how excessively risky choices by large banks can impact on a wide range of stakeholders, including taxpayers, and, more importantly, produce instability at the systemic level (Acharya et al., 2014; Becht et al., 2012). As a result a growing number of studies (see, for instance, Adams, 2012; Kirkpatrick, 2009; Ringe, 2013) and the media blame independent directors for not having played an effective advising and monitoring role in the years leading to the crisis. ${ }^{3}$ At the root of this criticism there is the view that the independent directors of banks should take into account the interests of the wide set of bank stakeholders that might be affected by bank business choices. Accordingly, they should favor a more prudent bank risk exposure even though this can go against the objective to maximize shareholder value (see Pathan, 2009, for a related argument).

Numerous regulators and policy makers express a similar view of independent directors post the crisis (see Dermine (2013) for a summary). While they respond to the crisis by reaffirming the importance of maintaining highly independent boards in banks, they increasingly identify good board practices with actions safeguarding wider stakeholder objectives (see the Basel Committee on Banking Supervision, 2010, 2015; European Union 2010; OECD, 2010). A good summary of this is contained in the 2010 report on how to enhance governance in banks, and in the following revisions, by the Basel Committee on Banking Supervision (2010) stating that “...board should take into account the legitimate interests of shareholders, depositors and other relevant stakeholders. It should also ensure that the bank maintains an effective relationship with its supervisors"' $\operatorname{pg}(7)$

The statement above confirms the request to go beyond a shareholder oriented approach to bank governance but it also reminds us that the supervisory authorities are part of the wider set of bank stakeholders and as such play an active role in shaping the career perspectives of independent directors (see Hopt, 2013, Ringe, 2013). Supervisors are required to obtain the information needed to evaluate the expertise and integrity of board members and conduct a fit and proper person test of bank directors (Basel

${ }^{3}$ For a critical view of the role played by independent directors during the crisis see, for instance, 'Corporate boards that do their job' Washington Post, 16 February 2009 A. 15, 'Where were the boards? Accountability shouldn't end with the CEO', Wall Street Journal, 25 October 2008. 
Committee on Banking Supervision, 2010), with the possibility of approving or denying a director's election and removing them from their role (see Hopt, 2013). Consequently, not complying with supervisory guidelines on what constitutes good board practice might have significant career implications in the market for bank directors.

Furthermore, in the attempt to establish more constructive governance systems in banks to monitor risk-taking, regulatory initiatives post the crisis attempt to ensure that the appointed independent directors have the appropriate abilities and tools to exercise an effective risk oversight on bank executives. For instance, the Basel Committee (2010) recommends that non-executive directors in large banks periodically meet the Chief Risk Officer in the absence of other senior managers while the EU Capital Requirements Directives (approved in 2013) stresses the importance of appointing directors with sufficient skills and time to understand bank risk-taking, and imposes limits on the number of directorships each director can hold. In a similar vein, the Dodd-Frank Act approved in the US in 2010 requires that banks establish risk committees including independent directors, with at least one being an expert in risk-management.

Overall, post the global crisis, independent directors are expected to account for wider stakeholder objectives and to do so they are expected to have the skills and time to exercise a more stringent risk oversight of banks. Accordingly, if the changing landscape of banking is effective in modifying bank board practices, we should observe board independence leading to greater reductions in risk in the years following the global crisis as compared to the rest of the sample period.

\section{Sample and Variables}

\subsection{Sample}

We use a sample of listed, large commercial banks and bank holding companies with accounting data available in BankScope by Bureau van Dijk and market data available in Datastream International. We select the sampled banks from an initial list consisting of the top 500 listed large commercial banks and bank holding companies across the globe in terms of total assets at the end of the fiscal year 2004. The sample period ranges from 2004 to 2014. More precisely, the dependent variables are observed over the period 
2005-2014, while the bank characteristics employed as explanatory variables are lagged one year to reduce endogeneity and simultaneity biases. As a result, they refer to the period 2004-2013.

From the initial list of the top 500 banks we retain in the sample institutions with governance data available from annual reports, governance reports and via web-searches of company websites, Bloomberg, Forbes and Business Week. Furthermore, given our analysis also relies on the estimation of market-based measures of risk, we exclude banks that in a given year have less than 80 daily stock returns and banks for which the majority of daily stock returns are equal to zero.

The final sample consists of 262 banks chartered in 45 countries with a total number of 2,309 observations. Despite the different selection criteria, our number of banks is similar to those employed in two recent cross-country studies that focus on the cross-sectional relationship between bank governance and performance during the global financial crisis (see Beltratti and Stulz, 2012; Erkens et al., 2012).4 Table 1 reports the sample distribution by country. A large number of banks are concentrated in Japan and in the US, with respectively $19.08 \%$ and $16.07 \%$ of the total number of observations. The high concentration of the sample in these two countries is consistent with Beltratti and Stulz (2012). For the remaining countries, a country's share in terms of total observations does not exceed 5\%.

$* * * * * * *$ TABLE $1 \mathrm{HERE} * * * * * * *$

\subsection{Measuring Bank Risk}

We employ accounting and market-based measures of bank risk in our analysis. Our accounting measure of risk is a bank's Z-Score, a widely used indicator of bank insolvency risk and risk-taking (see Beck et al., 2013; Boyd and Runkle, 1993; Houston et al., 2010; Laeven and Levine, 2009). The use of Z-Score as a risk measure is motivated by a notion of insolvency that occurs when bank losses are larger than the value of bank equity. Formally, the Z-Score is equal to the return on assets plus the equity to asset ratio all divided

${ }^{4}$ Specifically, Beltratti and Stulz (2012) employ a maximum number of 281 banks in their regression analysis (see Table 4, page 13), while Erkens et al. (2012) use a sample of 296 financial firms of which only 177 are classified as banks (see Table 1: Panel B, page 394$)$. 
by the standard deviation of asset returns. Given the highly skewed distribution of Z-Score, we employ its natural logarithm as a dependent variable in our tests, with the addition of a negative sign to indicate a higher bank risk in the presence of higher values. As in Boyd et al. (2006), we compute a panel data version of the Z-Score using an instantaneous measure of the standard deviation of bank ROA, defined as the absolute deviation of a bank's yearly ROA from the bank average ROA computed over the full sample period. By computing the standard deviation of bank asset returns in this way, and not on a rolling window basis, we avoid variations in the Z-Score capturing primarily the impact of past business policies. This is particularly important in the context of our analysis, as we aim at understanding if any change in the impact of board independence on risk emerges post the global crisis and we do not want to capture effects related to business choices that are prior to this possible change.

Accounting based measures of risk are, however, backward looking and may be affected by accounting manipulation that might especially materialize in terms of loss recognition. We, therefore, also use three market measures of bank risk that are more forward looking and less influenced by accounting discretion. The first is the volatility of bank daily stock returns computed yearly (Equity Volatility). The remaining two measures focus on the downside of bank risk expressed by the lower tail of the stock return distribution. As such, tail risk measures indicate the risk of severe wealth losses not only for shareholders but also for debtholders. This is because debtholders hold fixed claims on a bank's cash flows and the lower tail of the return distribution makes a loss of some of their principle more likely (Van Bekkum, 2016).

********TABLE 2 HERE ********

The first tail risk measure is a bank's Value at Risk (VaR) that corresponds to (minus) the daily stock return equal to the $\alpha$ percentile of the yearly distribution, reflecting the lowest return a bank can experience in $100(1-\alpha) \%$ of the trading days in a year. As in Van Bekkum (2016) we measure VaR as the negative value of the stock return corresponding to the $5^{\text {th }}$ percentile of the yearly distribution of daily stock returns. The second tail risk measure is the Expected Shorffall (ES). Following Ellul and Yerramilli (2013) and Van Bekkum (2016), ES is computed as the average return below the $5^{\text {th }}$ percentile of the yearly distribution of the daily stock returns. More formally, as suggested by Acharya et al. (2017), ES can be expressed as: 


$$
E S_{i}^{\alpha}=-E\left[R_{i, t} \mid R_{i, t}<-V a R_{i}^{\alpha}\right]
$$

where $R_{i, t}$ is the daily stock return for bank $i$ at day $t$ and $V a R_{i}^{\alpha}$ is a bank's Value-at-Risk. Conventionally, as shown by (1), to compute ES the average of the daily stock returns in the lower tail of the return distribution is multiplied by minus one. Hence, higher values of $E S$ indicate a higher bank tail risk.

Panel A of Table 2 reports summary statistics of the Z-score, and its components, and the three market measures of risk described in this section.

\subsection{Econometric Method and Control V ariables}

To estimate how the impact of board independence on bank risk changes after 2009 compared to the rest of the sample period we employ a fixed effect linear regression model that assumes the following functional form:

$$
\mathrm{Y}_{\mathrm{i}, \mathrm{t}}=\alpha_{\mathrm{i}}+\beta_{1} \text { BOARD INDEPENDENCE }+\beta_{2} \text { BOARD INDEPENDENCE } * \operatorname{POST}_{2009}+\beta_{3} \mathrm{POST}_{2009}+\delta \mathbf{B C}_{\mathrm{i}, \mathrm{t}-1}+\gamma \mathbf{C C}_{\mathrm{k}, \mathrm{t}}+\varepsilon_{\mathrm{it}} \quad(1)
$$

Where $Y_{i, t}$ is one of the risk variables described in the previous section, BOARD INDEPENDENCE is the ratio between the number of independent directors and the total number of board members, $\mathbf{B C}$ is a vector of bank-specific characteristics and $\mathbf{C C}$ is a vector of country-specific control variables. ${ }^{5}$ The key coefficient for our analysis is $\beta_{2}$ as it captures the change in the impact of board independence on bank risk after 2009. The use of a fixed effect model is motivated by the fact that differences in bank risk are partly due to bank characteristics that are not observable and constant across time (e.g. an institution's culture of risk management). The estimation of a separate intercept $\left(\alpha_{i}\right)$ for each bank before fitting the slope coefficients allows us to control for time-invariant sources of bank heterogeneity that are not observable

5 As in previous cross-country studies (see Erkens, et al., 2012; Onali et al., 2016), we measure board independence by employing the definition of independent directors as offered at the company level in compliance with the domestic regulation. This definition usually refers to directors that i) are not internal to the company; ii) are not characterized by any direct or indirect business relationship with the bank. 
and to focus on variations in risk at the level of individual banks over time. Furthermore, we cluster standard errors at the bank level to control for possible within group serial correlation.

Panels B and C of Table 2 report definitions and descriptive statistics for the explanatory variables. In the identification of the controls to include in our specification, we follow studies on the drivers of a bank's risk (see, for instance, Bertay et al., 2013; Hagendorff et al., 2017; Pathan, 2009). We control for bank size, measured via the log of bank total assets (Size), and the related importance of too-big to fail concerns. Additional bank-specific characteristics include the book-to market ratio (Book-to-Market), bank funding choices - defined as the ratio between customer deposits and bank total debts (Deposits), bank asset composition - measured by the ratio between total loans and total assets (Loans) and the riskiness of bank lending policy (Lending Risk) that we measure with the ratio between loan loss reserves and total loans.

We also include additional governance characteristics that are supposed to influence bank risk and the role of independent directors within an organization. The first variable is the log transformation of the number of board members (Board Size). The literature suggests that larger boards are easier controlled by managers. This is because the co-ordination problems among the board members increase as the board size increases (Bushman and Smith, 2001) and thus, a small board can be a more effective monitoring tool (Jensen, 1993; Pathan, 2009; Yermack, 1996).

A second governance variable refers to CEO characteristics and in particular to his/her power within the organization. A more powerful CEO might restrict the information flow to the board and hence reduce the board's independent oversight of managers and this might favor more prudent business choices (Fama and Jensen, 1983; Jensen, 1993). We measure CEO power (CEO Power) with an index constructed as the sum of three dummy variables. The first dummy variable is equal to one if the $\mathrm{CEO}$ has been internally appointed to his/her current role, signaling a longer working experience inside the bank that should lead to greater power (Pathan, 2009). The second dummy variable is equal to one if the CEO is also the chairman of the board; in such a case, the CEO should be characterized by greater power within the corporation (Pathan, 2009). The third variable is equal to one if the CEO is the only non-independent director in the board, signaling therefore his/her centrality to the information flow between the board and other senior 
members of the executive team (Faleye, 2015; Joseph et al., 2014). The index ranges, therefore, from zero to three with larger values denoting greater CEO power.

We then control for a bank's ownership structure via the percentage of shares held by institutional shareholders (Institutional Shareholders) that we obtain from Capital IQ. Institutional shareholders are supposed to have a larger capability to monitor managers (Agrawal and Mandelker, 1990; Burns et al., 2010) and larger diversification opportunities than other shareholders. These factors might, therefore, impact on bank business policies and the related risk-taking.

In terms of country controls, as in Carbó-Valverde et al. (2013), we account for the degree of corruption at the country level to reflect cross-country differences in a government's susceptibility to regulatory capture. We measure corruption (Corruption) as minus the Freedom from Corruption Index, provided by the Heritage Foundation, with higher values denoting higher corruption in a country. The index from Barth et al. (2001), and the related surveys from the World Bank, on the strength of the supervisory agency in a country (Supervisory Strength) allows us to control for the potential impact on bank risk from differences in the supervisory structure across countries. We also add a dummy equal to one when a country has abandoned Basel I over the sample period (No Basel I) with the purpose of controlling for the influence of the capital regulatory regime and we control for the degree of concentration of the domestic banking market (Concentration) that is supposed to be related to bank risk (see Allen et al., 2011; and Beck et al., 2005).

The annual growth rate in real GDP (GDP Growth) is employed to control for the effect of the business cycle on the evolution of bank business choices, while the ratio between public debt and country GDP (Public Debt) controls for possible differences in the capacity of countries to rescue financial institutions. Furthermore, following Laeven and Levine (2009) we also control for the GDP per capita (Econ_Dev) to account for differences in risk due to differences in economic development across countries. As studies on non-financial firms show higher risk-taking in countries characterized by a higher protection of shareholder interests (John et al., 2008), the model includes an index measuring shareholder protection (Shareholder Protection), drawn from Doing Business by World Bank. Finally, as in Carbó-Valverde et al. (2013), we 
control for the volatility of the domestic stock market defined by the Datastream Domestic Market Index

(Market Volatility) to remove the possibility that our risk measures, especially the market based measures, capture general market trends and not the idiosyncratic choices of banks.

\section{Board Independence and Bank Risk and the Changes Post the Global crisis}

\subsection{Baseline results}

In this section we test whether the impact of board independence on accounting and market based measures of bank risk changes post 2009; namely, after the global financial crisis. We report the results of this analysis in Table 3. We start by estimating in column (1) a model where the dependent variable is the negative value of the log transformation of a bank's Z-score and with a limited number of controls (in addition to board independence and its interaction with the post-2009 dummy). Specifically, in this specification we control only for bank size, and for the set of country controls described in section 3.3. Notably, to reduce the risk of multicollinearity, and to ease the interpretation of our results, we follow Vallascas and Hagendorff (2013) and adopt a demean approach in constructing the interaction term between board independence and the post-2009 dummy. This approach consists of subtracting the respective sample mean from board independence before computing the interaction term. As a result, under this specification the coefficient of the post-2009 dummy refers to a bank with an average degree of board independence (that is, when the interaction term is equal to zero).

The next two specifications include additional bank characteristics (column (2)) that are supposed to affect a bank's risk, and additional governance controls (column (3)). We then replicate these two latter specifications (columns (4) to (9)) using as dependent variables the market measures of bank risk that we describe in section 3.2. Notably, in this case we also add the equity ratio as a further control variable.

\section{***TABLE 3 HERE***}

The results consistently suggest that post-2009, there is a significant decrease in the coefficient associated with board independence as indicated by the negative and highly significant coefficient of the interaction between board independence and the post-2009 dummy. This negative coefficient of the interaction suggests that the way independent directors of large banks interpret their mandate has 
significantly changed after 2009, becoming more aligned with the objective of avoiding excessive risk-taking by banks.

The result mentioned above holds under the different model specifications reported in Table 3 especially, it is confirmed for both accounting and market measures of bank risk. Notably, the coefficient associated with board independence for the period 2004-2009 (that is, when the interaction term is equal to zero) is insignificant in all models, showing, therefore, that independent directors did not help to mitigate bank risk-taking in the period culminating with the global financial crisis. The lack of impact of board independence on bank risk is in line with the evidence reported in a number of recent studies (Anginer et al., 2016; Erkens et al., 2012; Minton et al., 2014).

In terms of control variables, we find that our fixed effect models identify numerous bank and country characteristics that significantly affect bank risk. For instance, we find that all measures of risk decline when a bank's funding structure is based on customer deposits and increases when banks take more risk via their lending business. In the case of market measures of risk, we also find that risk increases when banks have a lower charter value (higher book-to-market ratio), are less capitalized or have more institutional shareholders in their ownership structure. Interestingly, we do not find consistent results on how other governance characteristics, such as board size and CEO power, affect bank risk.

Moving onto the analysis of country controls, our results show that bank risk increases in countries with greater stock market volatility and declines in the presence of higher GDP growth or public debt over GDP. This latter result is in line with the view that banks might reduce their risk-taking when located in countries with a lower bailout capability (Hagendorff et al., 2017). The impact of banking system characteristics (Supervisory Strength, No Basel 1 and Concentration) depends on the way we measure bank risk.

Overall, our findings indicate that after 2009 independent directors seem to be more inclined to exercise a stronger risk-oversight on banks, thus becoming more aligned with the view that bank boards should become a line of defense not only for bank shareholders but also for the wider set of bank stakeholders. 


\subsection{Additional Tests}

In this section we discuss the results of a series of additional tests aimed at assessing the robustness of our findings. In the interest of brevity we report the results of these tests in Table A1 in the Online Appendix.

The use of a fixed effect model, while helpful in reducing omitted variable problems due to unobservable time-invariant bank characteristics, substantially removes cross-sectional variation across banks by only focusing on within-firm variation. To understand whether our results change when we account for variation across banks, we re-estimate the models in Table 3 by using a random effect specification with country dummies. We do not find significant changes in our findings.

Another possible concern related to the results discussed above is the endogeneity of several right-hand side variables and in particular board independence. One key source of endogeneity is reverse causality. For instance, it might be the case that bank risk-taking drives the appointment of independent directors (with these directors that might be inclined, for instance, to avoid very risky institutions because of reputational concerns). While this concern is mitigated by our fixed effect specification based on lagged values of the explanatory variables, we employ several additional empirical strategies to control for reverse causality.

Initially, we follow Boone et al. (2007), Faleye et al. (2014) and Faleye (2015) among others that deal with reverse causality by regressing the dependent variable on longer lagged values of the potentially endogenous explanatory variables. The intuition here is that such historical values are largely predetermined (Faleye, 2015). Accordingly, we re-estimate the equations with the explanatory bank-characteristics (including board independence) that are lagged two years. The results still confirm our key findings.

Next, as in Wintoki et al. (2012), we control for endogeneity by using a two-step system GMM dynamic panel model (Blundell and Bond, 1998) with standard errors adjusted as suggested by Windmeijer (2005). This approach relies on lagged values of the endogenous variables as instruments in the difference equation and on the first-difference of the same variables in the level equation. This method is appropriate to control for forms of dynamic endogeneity that arise when an explanatory variable is correlated with past values of the dependent variable, as is often the case in governance studies (Wintoki et al., 2012). We treat all firm 
characteristics as endogenous and limit the number of instruments using the values at time $\mathrm{t}-2$ as instruments in the difference equation and the first lag difference in the level equations. The conventional tests employed to validate this setting (the $\mathrm{m} 2$ test on the lack of second order serial correlation and the Hansen J test on instrument validity) support our choice and the results confirm our key findings. ${ }^{6}$

Finally, we estimate an instrumental variable (IV) fixed effect model (with contemporaneous explanatory variables). While, as suggested by Adams and Mehran (2012), it is problematic to identify an appropriate instrument in governance studies, in our context some support comes from the cross-country dimension of our analysis. We identify the first instrument on the basis of cross-country differences in media influence that Dyck and Zingales (2004) link to a decline in the potential private benefits that senior managers can extract from corporations. Higher media influence should then reduce the need for board independence. We capture media influence via the log transformation of the ratio between the number of daily newspapers in circulation and the total population in a country. The second instrument is motivated by studies showing that similar corporations opt for similar governance models (Faleye, 2015, Joseph et al., 2014). A benchmark constructed for different groups of banks might, therefore, explain variation in the percentage of independent directors across banks. We cannot, however, employ any industry benchmark as in Faleye (2015) or a country benchmark (given the low number of banks in some of the countries). We use instead as an instrument the median degree of board independence by groups of banks aggregated on the basis of the legal origin of the country of residence and the size of the banking system. We define the legal origin of a country following La Porta et al. (1998). Furthermore, we classify banks as operating in small or large banking systems on the basis of the median value of a banking system total assets computed on an annual basis. Finally, we require that for each group of banking firms there are at least four yearly observations

${ }^{6}$ In the case of the two market risk measures (Equity Volatility and VaR), the model requires adding a two lag period of the dependent variable to remove serial correlation and validate the GMM specification. 
before calculating the yearly median of board independence. 7,8 The second stage regression confirms our key findings for three out of the four risk measures.

Overall, taken together the tests reported in this section add confidence to our findings. However, as in any governance study, it is challenging to reach an unambiguous causal interpretation of the findings. Nevertheless, at minimum, our analysis is suggestive of the presence of a strong, and robust change in the association between risk and board independence after the global financial crisis.

\subsection{Board Independence and the Z-Score Components}

Another way to exclude the possibility that our results are spurious is to conduct additional tests that employ the components of the Z-Score (namely, ROA, the Equity Ratio and ROA Volatility) as dependent variables. Given the results reported in the first three columns of Table 3, we should observe that i) the impact of board independence on at least some of these variables differs post 2009 (compared to the rest of the sample period) and ii) the observed differential impact should be consistent with an enhanced riskdecreasing effect of board independence on bank insolvency risk in the second part of our sample period.

***TABLE 4 HERE***

7 Another complication is the fact that the interaction terms between board independence and the post-2009 dummy might be plausibly endogenous. Accordingly, we use the interactions between the two instruments described above and the post-2009 dummy as instruments for the endogenous interaction terms.

8 The instruments have to satisfy two conditions. First, they have to be correlated with the endogenous variable after all other exogenous variables are controlled for. The results of the first-stage regression (available upon request) show that both instruments enter the model with a significant coefficients and the expected sign. Furthermore, as shown in the Online Appendix, we reject (at the 5\%-level) the Kleibergen-Paap LM statistic that tests the null hypothesis that the instruments are weakly correlated with the endogenous variables. Second, the instruments should not be correlated with the error term of the second-stage regression. The fact we cannot reject the Hansen test, where the null hypothesis is that all instruments are valid, indicates that also the second condition is satisfied. 
To conduct these additional tests, we re-estimate the models shown in columns (2) and (3) of Table 3 using each of the components of the Z-Score as a dependent variable. We report the results of these tests in Table 4.

The first two columns of Table 4, where a bank's ROA is the dependent variable, do not indicate a significant shift in the sensitivity of bank profitability to board independence post 2009. In short, we do not find that board independence matters for bank profitability and we do not find any different effect post 2009.

The analysis based on the other two components of the Z-Score offers, however, a different picture. For both components we find evidence of a shift in the impact played by board independence post 2009 and this shift is consistent with a more prudent risk-taking attitude by independent directors in the second part of our sample period.

Specifically, when the dependent variable is a bank's equity ratio we find a larger positive coefficient of board independence post 2009. Moving onto the analysis of bank ROA volatility, we observe a larger negative coefficient assigned to board independence post 2009. These findings indicate that there are two channels by which board independence impacts on bank Z-score differently after the global crisis. The first is in terms of strengthening a bank's capital adequacy post-crisis. The second channel is through a decline in portfolio risk. This latter result is also in line with the evidence that we obtain from the tail risk regressions indicating that banks with more independent boards are less willing to engage in business policies that expose the organization to extreme losses after the global crisis as compared to the rest of the sample period.

To recap, the results discussed in this section provide additional support for a significant shift in the way independent directors interpret their role after the global financial crisis and this shift is consistent with independent directors favoring less aggressive risk-taking policies by banks post 2009 .

\section{Is there a Generalized Shift in the Role of Board Independence Post the Global Crisis?}

The post-2009 results indicate a shift in the role played by independent boards in our sample of large banks. This shift is coherent with the argument that post the crisis independent directors have been 
influenced by the growing pressure to safeguard wider stakeholder objectives that emerges in the banking industry and by the related request that these directors exercise a stronger risk oversight of bank executives.

Our analysis, however, does not necessarily imply a generalized shift in the impact of board independence on bank risk. In fact, our results could be confined to some specific large banking firms. In this respect, some of the banks in our sample have produced significantly larger damages for creditors and taxpayers, and consequently placed larger costs on public finances, in the aftermath of the global crisis. As a result, these banks have been subject to heavier regulatory and media scrutiny that is likely to affect their board composition and how independent directors interpret their role post-crisis. Therefore, our results might be observable in banks receiving a government bailout but not necessarily in the rest of the sampled banks. In such a case, the importance of board independence as a governance mechanism to constrain bank excessive risk-taking would be still marginal even after the global financial crisis.

In this section, we present a series of tests that aim to show how our analysis differs between bailout banks and the remaining banks in our sample.

\subsection{Large Bank Bailouts and Board Independence}

We start by offering evidence motivating the strong criticism of the role independent directors played in bailout banks. Essentially, we aim to show that having more independent boards before the crisis did not contribute to reducing the likelihood that banks required public support to be recapitalized and the related costs on taxpayers. To this end, we relate pre-crisis bank characteristics (measured at the end of 2006), including board independence, to the negative impact produced by banks on taxpayers and public finances. We use two proxies for the negative impact that banks have produced on taxpayers. The first is a dummy equal to one if a bank receives capital support during the crisis. The second is the aggregate value of public 
funds a bank has received scaled by the volume of bank total assets at the end of $2006 .{ }^{9}$ We identify 54 banks in the sample that have received capital support in the period 2007-2009.

We regress the above measures on board independence and a set of controls including bank characteristics used in our previous tests. Furthermore, we control for the marginal expected shortfall (MES) measured as in Acharya et al. (2017), indicating the degree of systemic risk characterizing a bank in 2006 (as more systemically relevant banks might have a higher likelihood of receiving public support), and for the value of bank implicit government subsidy received by a bank in 2006, named as IPP, that, as described in the Appendix, we estimate as in Carbó-Valverde et al. (2012) and Hovakimian, and Kane (2000). ${ }^{10}$ Larger values of IPP indicate that banks extract more value from the financial safety net by engaging in risk-shifting strategies at the expense of taxpayers. The models also include country dummies.

When we employ the dummy indicating a bailout as a dependent variable, we conduct our analysis via a logit model, while we employ a Tobit regression when the dependent variable is defined by the value of the received public funds scaled by total assets. In this latter case, the dependent variable is left censored because of the presence of a number of banks that did not require public funds in the period under investigation.

***TABLE 5 HERE***

${ }_{9}$ We draw data on public funded recapitalizations from ProPublica (http://projects.propublica.org/bailout/list) for U.S. financial institutions, from Mediobanca (2014) for European financial institutions, and from annual reports as well as company websites and from the Grail Report (2009) for the remainder of the sample.

${ }^{10}$ IPP is based on the model proposed by Duan et al. (1992). In this model, banks can increase the fair value of the deposit insurance premium (namely, the value that would be appropriate to pay to the deposit insurance fund) by increasing leverage and portfolio risk. In this model, the fair insurance premium assumes the form of a put option written on bank assets. To put it differently, IPP represents the amount of insurance premium a bank should pay to allow taxpayers to break-even if they were to hedge the bank's tail risk shifted to them. Therefore, under the assumption that the insured premium actually paid by banks is negligible, IPP is a proxy of the safety-net benefits that banks extract from taxpayers. 
We report the results of these tests in Table 5. Overall, we find that an increase in board independence does not help to reduce the likelihood of a bailout or the value of a bank recapitalization via public funds. In contrast, banks entering the crisis with a higher degree of board independence need more public funds per unit of bank assets to restore their capital levels. This latter result is confirmed when we change the model specification and, as shown in columns 4) and 5) of Table 5. Further, it also holds when we estimate the model on the sub-sample of US banks. Interestingly, in most of the specifications we find that banks that benefited from a larger mispricing of government guarantees before the crisis (as measured by IPP) required more public funds in response to the crisis.

In summary, the tests discussed in this section show that independent directors in large banks were ineffective in containing the costs of the global crisis for taxpayers. In contrast, more independent boards before the crisis lead to higher rescue costs for the public finances.

\subsection{The Changing Impact of Board Independence on Bank. Risk. Post the Global Crisis for Bailout and Non-Bailout Banks}

A key implication of the results of the above test is that independent directors sitting on the boards of bailout banks are likely to face even more pressure post bailout to safeguard wider stakeholder objectives and to exercise a stronger risk oversight than independent directors on the boards of other banks. We investigate the validity of this argument in Table 6 where we re-estimate the risk regressions reported in Table 3 by differentiating in the post-crisis period bailout banks from the remaining banks in the sample. Specifically, from the original post 2009 dummy, we construct two variables: the first is a dummy equal to one after 2009 only for the sampled banks that did not receive public funds while the second refers to the recapitalized banks via a bailout. We then interact these two dummies with board independence in the risk regressions.

***TABLE 6 HERE***

The results consistently indicate that only the interaction between board independence and the dummy variable referring to bailout banks is negative and highly significant. For the remaining banks in the sample, we do not find that board independence has a different influence on bank risk post 2009 as compared to 
the rest of the sample period. The result we observe post 2009 is, therefore, driven by banks rescued via public funds and does not extend to all banks in our sample. In short, independent directors opt for a more stakeholder-oriented approach and stronger risk-oversight only in those banks that are under heavy regulatory and media scrutiny because of the costs placed on public finances (and the related damages for bank creditors and taxpayers).

In Table A2 in the Online Appendix, we repeat the analysis using an alternative empirical setting. Specifically we repeat the tests separately for the bailout and non-bailout banks. This allows us to control for other potential differences in the determinants of bank risk between the two sub-samples. In line with the results reported above, we find that only in the group of bailout banks is the interaction term between the post crisis dummy and the degree of board independence negative and significant at customary levels.

We next repeat the above tests for the sub-sample of US banks. The focus on a single country, for which we have a significant number of bailouts, reduces the possibilities that our results are somehow driven by omitted factors. In general, as reported in Table A3, our results remain in line with the full sample analysis.

To recap, the results presented in this section show that board independence has a different impact on bank risk post 2009 but only in the case of banks requiring public support to survive the global financial crisis. To put it differently, while we do not find evidence of a generalized shift in the risk-taking attitude of independent boards of large banks post 2009, we do find that the post 2009 result is driven by the boards of bailout banks.

\subsection{Board Independence and the Z-Score Components on Bailout and Non-Bailout Banks}

We next extend the analysis by using the Z-Score components as dependent variables. In essence, in the case of the Z-Score, we try to understand through which channels the changes in the risk-taking attitude observed for the independent boards of bailout banks materialize post-crisis. We report the results of these additional tests in Table 7.

As shown in columns (5) and (6), we find that for the group of bailout banks the different impact of board independence on Z-Score post 2009 materializes via a significant decline in ROA volatility as 
indicated by the negative and highly significant coefficient of the interaction between board independence and the dummy variable identifying rescued banks for the years following the crisis.

In contrast, as in the case of the results reported in Table 3, we do not find that the impact of board independence on bank profitability changes post 2009 for both bailout and non-bailout banks. Furthermore, more independent boards in bailout banks do not mitigate bank risk by strengthening the capital adequacy more than other boards post 2009. Essentially, as shown in columns (3) and (4) of Table 7, while all banks in our sample experience an increase in their capital ratios post 2009, only in the group of non-bailout banks is this increase amplified by the degree of board independence.

When we repeat the analysis for the sub-sample of US banks we achieve similar conclusions. In other words, as shown by Table A4 in the Online Appendix, we still find a different effect of board independence on the Z-score component post 2009 only in the regression that uses ROA volatility as the dependent variable but only for bailout banks.

\section{***TABLE 7 HERE***}

All in all, these tests indicate that the primary channel by which board independence influences the Zscore of bailout banks post-crisis is by constraining the ROA volatility; namely, by emphasizing business policies that reduce bank portfolio risk.

\section{Conclusions}

Recent empirical studies on bank boards do not unequivocally associate a growing board independence with more stable banks (see, for instance, Adams, 2012; Anginer et al., 2016; Erkens et al., 2012; Minton et al., 2014). While these studies offer evidence primarily from the pre-crisis or crisis periods, in this paper we take a different perspective. Specifically, we test whether the impact of board independence on bank risktaking has changed post the global crisis as compared to the period culminated with the crisis.

Our analysis is motivated by a number of post crisis regulatory reports and initiatives indicating the importance of bank boards as tools to safeguard wider stakeholder objectives and not simply the interests of shareholders (Basel Committee on Banking Supervision 2010; 2015) and by the related request of a 
stronger risk oversight of bank executives by independent boards. In general, these two aspects have the potential to influence the reputational incentives faced by independent directors in the labor market and the types of independent directors sought by bank boards in the post crisis period with the consequence to make board independence a more effective risk-mitigating mechanism post the crisis.

By using a sample of large international banks, our initial analysis offers strong evidence that more independent boards change their risk-taking attitude post 2009, hence supporting our initial conjecture. In short, for both accounting and market based measures of risk, we find an enhanced risk-decreasing effect of board independence after the crisis. This effect is accompanied by more independent boards favoring increases in capital strength and declines in ROA volatility post the crisis.

Additional tests demonstrate, however, that our initial finding does not reflect a generalized shift of the impact of board independence on bank risk that applies to all the banks in our sample. Instead, we show that the above result is driven by the sub-sample of banks receiving a government bailout around the global financial crisis. In fact, for the rest of the banks in our sample, the degree of board independence does not seem to matter for bank risk-taking in spite of the changes in regulatory attitudes post the crisis.

Overall, our results imply that the impact of board independence on risk-taking in large international banks remains somewhat limited and insufficient to safeguard the interests of bank creditors and taxpayers. The limited effectiveness of internal governance mechanisms in the form of independent boards that we observe in our study suggests that the need to strengthen the external monitoring by regulators and supervisors on large banks remains critical if financial stability is to be protected. 


\section{References}

Acharya, V. V., Pedersen, L. H., Philippon, T., and Richardson, M. P. 2017. Measuring systemic risk. Review of Financial Studies 30, 2-47.

Acharya, V.V., Drechsler, T., and Schnabl, P., 2014. A Pyrrhic Victory? Bank bailouts and sovereign credit risk. The Journal of Finance Vol. LXIX, 2689-2739.

Adams, R.B., 2012. Governance and the financial crisis. International Review of Finance 12, 7 - 38.

Adams, R.B., Hermalin, B., and Weisbach, M., 2010. The role of boards of directors in corporate governance: A conceptual framework and survey. Journal of Economic Literature, 58-107.

Adams, R.B., and Mehran, H., 2012. Bank board structure and performance: Evidence for large bank holding companies. Journal of Financial Intermediation 21, 243-267.

Agrawal, A., and Mandelker, N., 1990. Large shareholders and the monitoring of managers: The case of antitakeover charter amendments. Journal of Financial and Quantitative Analysis 25, 143-161.

Allen, F., Carletti, E., and Marquez R., 2011. Credit market competition and capital regulation. Review of Financial Studies 24, 983-1018.

Anginer, D., Demirguc-Kunt, A., Huizingac, H., and Ma, K., 2016. Corporate governance and bank capitalization strategies. Journal of Financial Intermediation 26, 1-27.

Barth, J.R., Caprio, G., and Levine, R., 2001. The regulation and supervision of banks around the world: a new database. In: Litan, R.E., Herring, R. (Eds.), Integrating Emerging Market Countries into the Global Financial System, Brookings-Wharton Papers in Financial Services, Brooking Institution Press: Washington.

Basel Committee on Banking Supervision, 2010. Principles for enhancing corporate governance. Switzerland.

Basel Committee on Banking Supervision, 2015. Principles for enhancing corporate governance. Switzerland.

Becht, M., Bolton, P., and Roell, A., 2012. Why bank governance is different. Oxford Review of Economic Policy 27, 437-463.

Beck, T., De Jonghe, O., and Schepens, G. 2013. Bank competition and stability: Cross-country heterogeneity. Journal of Financial Intermediation 2, 218-244.

Beck, T., Demirgüç-Kunt, A., and Levine, R., 2005. Bank concentration, competition, and rises: First results. Journal of Banking and Finance 30, 1581-603.

Beltratti, A., and Stulz, R., 2012. The credit crisis around the globe: why did some banks perform better? Journal of Financial Economics 105, 1-17.

Berger, A.N., Kick, T., and Schaeck, K., 2014. Executive board composition and bank risk taking. Journal of Corporate Finance 28, 48-65.

Berger, A. N., and Roman R. A., 2015. Did TARP Banks Get Competitive Advantages? Journal of Financial and Quantitative Analysis 50, 1199-1236. 
Bertay, A.C., Demirgüc-Kunt, A., and Huizinga, H., 2013. Do we need big banks? Evidence on performance, strategy and market discipline. Journal of Financial Intermediation 22, 532-558.

Black, L., and Hazelwood, L., 2013. The effect of TARP on bank risk-taking. Journal of Financial Stability 9, 790-803

Blundell, R., and Bond, S., 1998. Initial conditions and moment restrictions in dynamic panel data models. Journal of Econometrics 87, 115-143.

Bolton, P., Mehran, H., and Shapiro, J. 2015. Executive compensation and risk taking. Review of Finance 19, 21392181.

Boone, A., Field, L.C., Karpoff, J.M., and Raheja C.G., 2007. The determinants of corporate board size and composition: An empirical analysis. Journal of Financial Economics 85, 66-101.

Boyd, J., De Nicolò, G., and Jalal, A., 2006. Bank risk-taking and competition revisited: new theory and new evidence. IMF Working Paper 06/297, Washington DC: International Monetary Fund.

Boyd, J.H., and Runkle, D.E., 1993. Size and performance of banking risk: Testing the predictions of theory. Journal of Monetary Economics 31, 47-67.

Brandao-Marques, L., Correa, R., and Sapriza, H., 2012. International evidence on government support and risk-taking in the banking sector. IMF Working Paper.

Burns, N., Kedia, S., and Lipson, M., 2010. Institutional ownership and monitoring: Evidence from financial misreporting. Journal of Corporate Finance 16, 443-455.

Bushman, R.M., and Smith, A.J., 2001. Financial accounting information and corporate governance. Journal of Accounting and Economics 31, 237-333.

Carbó-Valverde, S., Kane E., and Rodriguez, F., 2012. Regulatory arbitrage in cross-border mergers within the EU. Journal of Money Credit and Banking 44, 1609-1629.

Carbó-Valverde, S., Kane E., and Rodriguez, F., 2013. Safety-net benefits conferred on difficult-to-fail-and-unwind banks in the US and EU before and during the great recession. Journal of Banking and Finance 37, 1845-1859.

Coles, J. L., and Hoi, C., 2003. New evidence on the market for directors: Board membership and Pennsylvania Senate Bill 1310. Journal of Finance 58, 197-230.

Coles, J.L., Naveen, D.D., and Naveen, L., 2008. Boards: Does one size fit all? Journal of Financial Economics 87, $329-356$.

Dermine J., 2013. Bank corporate governance, beyond the global banking crisis. Financial Markets, Institutions and Instruments 22, 259-281.

Dodd-Frank Act, 2010. Dodd-Frank Wall Street Reform and Consumer Protection Act, Public Law 111-203-July 21, 1214 Stat. 1326.

Duan, J.C., Moreau, A., and Sealey, C.W., 1992. Fixed-rate deposit insurance and risk shifting behavior at commercial banks. Journal of Banking and Finance 16, 715- 742. 
Duchin R., and Sosyura, D., 2014. Safer ratios, riskier portfolios: banks' response to government aid. Journal of Financial Economics 113, 1-28.

Dyck, A., and Zingales, L., 2004. Private benefits and control: An international comparison. The Journal of Finance LIX, 537-600.

Erkens, D., Hung, M. and Matos, P., 2012. Corporate governance in the 2007-2008 financial crisis: Evidence from financial institutions Worldwide. Journal of Corporate Finance 18, 389-411.

European Union, 2010. Green Paper on Corporate Governance in Financial Institutions and Remuneration Policies, $1-19$.

Faleye, O., 2015. The costs of a (nearly) fully independent board. Journal of Empirical Finance 32, 49-62.

Faleye, O., Kovacs, T., and Venkateswaran, A., 2014. Do better-connected CEOs innovate more? Journal of Financial and Quantitative Analysis 49, 1201-1225.

Fama, E.F., and Jensen, M.C., 1983. Separation of ownership and control. Journal of Law and Economics 26, 301325.

Farrell, K. A., and Whidbee. D.A., 2000. The consequences of forced CEO succession for outside directors. Journal of Business 73, 597-627.

Ferris, S. P.,M. Jagannathan, and A. C. Pritchard. 2003. Too busy to mind the business? Monitoring by directors with multiple board appointments. Journal of Finance 58:1087-112.

Fich, E.M., and Shivdasani, A., 2007. Financial fraud, director reputation, and shareholder wealth. Journal of Financial Economics 86, 306-336.

Flannery, M.J., and Sorescu, S.M., 1996. Evidence of bank market discipline in subordinated debenture yields: 19831991. The Journal of Finance 51, 1347-1377.

Gilson, S. C. 1990. Bankruptcy, boards, banks, and blockholders: Evidence on changes in corporate ownership and control when firms default. Journal of Financial Economics 27, 355-387.

Grail Research, 2009. Global financial crisis, bailout/stimulus tracker. September 12.

Hagendorff, J., Keasey, K., and Vallascas F., 2017. When banks grow too big for their national economies: Tail risks, risk channels and government guarantees. Unpublished Working Paper.

Harford, J. 2003. Takeover bids and target directors' incentives: The impact of a bid on directors' wealth and board seats. Journal of Financial Economics 69, 51-83.

Hermalin, D., and Weisbach, M., 2003. Boards of directors as an endogenously determined institution: A Survey of the Economic Literature. Economic Policy Review 9, 7-26.

Hopt, K. J., 2013. Better governance of financial institutions. ECGI Working Paper n. 207/2013.

Houston, J.F., Chen, L., Ping, L., and Ma. Y., 2010. Creditor rights, information sharing, and bank risk taking. Journal of Financial Economics 3, 485-512. 
Hovakimian, A., and Kane, E.J., 2000. Effectiveness of capital regulation at U.S. commercial banks, 1985 to 1994. The Journal of Finance 55, 451-468.

Jagannathan, M., Krishnamurthy, S., and Spizman, J., 2015. On the timing of director departures. Unpublished Working Paper.

Jensen, M.C., 1993. The modern industrial revolution, exit and the failure of internal control systems. The Journal of Finance 48, 831-880.

Jensen, M.C., and Meckling, W.H., 1976. Theory of firm: Managerial behavior, agency costs and ownership structure. Journal of Financial Economics 3 305-460.

Jiang, W., Wan, H., and Zhao, S., 2015. Reputation concerns of independent directors: evidence from individual director voting. Review of Financial Studies, forthcoming.

John, K., Litov, L., and Yeung, B., 2008. Corporate governance and risk-taking. The Journal of Finance 63, 16791728.

Joseph, J., Ocasio, W., and McDonnell, M., 2014. The structural elaboration of board independence: executive power, institutional logics, and the adoption of CEO-only board structures in U.S. corporate governance. Academy of Management Journal 57, 1834-1858.

Kirkpatrick, G., 2009. The Corporate Governance Lessons from the Financial Crisis', Financial Markets Trends, 2009/1, OECD.

Laeven, L., and Levine, R., 2009. Bank governance, regulation and risk taking. Journal of Financial Economics 93, $259-275$.

La Porta, R., Lopez-de-Silanes, F., Shleifer, A., and Vishny, R.W., 1998. Law and finance. Journal of Political Economy $106,1113-1155$.

Lepetit, L., Tarazi, A., and Zedek, N., 2015. Excess control rights, bank capital structure adjustments and lending. Journal of Financial Economics 115, 574-591.

Masulis, R.W., and Mobbs, H.S., 2014. Independent director incentives: Where do talented directors spend their limited time and energy? Journal of Financial Economics, 111, 406-429.

Masulis, R.W., and Mobbs, H.S., 2016. Supply and demand for independent director services: Major board decisions and corporate outcomes. Unpublished Working Paper.

Mediobanca, 2014. Interventi dei governi nazionali a favore delle banche e degli istituti finanziari in Europa e negli Stati Uniti dal ssettembre 2007 al giugno 2012. [Government interventions in favor of banks and financial institutions in Europe and in the US from September 2007 to December 2013] https://www.mbres.it/sites/default/files/resources/download it/rs Piani\%20di\%20stabilizzazione\%20finanziaria. pdf.

Minton, B., Taillard, J.P.A., and Williamson, R., 2014. Financial expertise of the board, risk taking, and performance: evidence from bank holding companies. Journal of Financial and Quantitative Analysis 49, 351-380. 
OECD, 2010. Corporate governance and the financial crisis. OECD Steering Group on Corporate Governance. Paris, 1-34.

Onali E., Galiakhmetova, R., Molyneaux, P., and Torluccio, G., 2016. CEO power, government monitoring, and bank dividends. Journal of Financial Intermediation 27, 89-117.

Pathan, S. 2009. Strong boards, CEO power and bank risk-taking. Journal of Banking and Finance 33, 1340-1350.

Ringe, W.G., 2013. Independent directors: after the crisis. European Business Organization Law Review 41, 401-424.

Ronn, E.I., and Verma, A.K., 1986. Pricing risk-adjusted deposit insurance: An option-based model. The Journal of Finance 41, 871-896.

Vallascas, F., and Hagendorff, J., 2013. The risk sensitivity of capital requirements: Evidence from an international sample of large banks. Review of Finance 17, 1947-1988.

Van Bekkum, S., 2016. Inside Debt and Bank Risk, Journal of Financial and Quantitative Analysis 51, $359-385$.

Vassalou, M., and Y. Xing. 2004. Default risk in equity returns. The Journal of Finance 59, 831-868.

Wagner, A., F., 2011. Board independence and competence. Journal of Financial Intermediation 20, 71-93.

Windmeijer, F., 2005. A finite sample correction for the variance of linear efficient GMM estimators, Journal of Econometrics 126, 25.51 .

Wintoki, M.B., Linck, J.S., and Netter, J. M., 2012. Endogeneity and the dynamics of corporate governance, Journal of Financial Economics 105, 581-606.

Yermack, D., 1996. Higher market valuation of companies with a small board of directors. Journal of Financial Economics 40, 185-212.

Zhang, Q. Vallascas, F., Keasey, K., and Cai C., 2015. Are market measures of global systemic importance of financial institutions useful for regulators and supervisors? Journal of Money Credit \& Banking 47, 1403-1442. 
Table 1: Sample Distribution by Country

\begin{tabular}{|c|c|c|c|c|}
\hline & \multicolumn{2}{|c|}{ Banks } & \multicolumn{2}{|c|}{ Observations } \\
\hline & Number & Percentage & Number & Percentage \\
\hline Australia & 5 & 1.91 & 44 & 1.91 \\
\hline Austria & 4 & 1.53 & 33 & 1.43 \\
\hline Belgium & 3 & 1.15 & 24 & 1.04 \\
\hline Brazil & 2 & 0.76 & 20 & 0.87 \\
\hline Canada & 7 & 2.67 & 70 & 3.03 \\
\hline Chile & 2 & 0.76 & 16 & 0.69 \\
\hline China & 12 & 4.58 & 91 & 3.94 \\
\hline Cyprus & 1 & 0.38 & 7 & 0.3 \\
\hline Czech Republic & 1 & 0.38 & 10 & 0.43 \\
\hline Denmark & 3 & 1.15 & 27 & 1.17 \\
\hline Finland & 1 & 0.38 & 10 & 0.43 \\
\hline France & 4 & 1.53 & 39 & 1.69 \\
\hline Germany & 7 & 2.67 & 57 & 2.47 \\
\hline Greece & 6 & 2.29 & 53 & 2.3 \\
\hline Hong Kong & 3 & 1.15 & 30 & 1.3 \\
\hline Hungary & 1 & 0.38 & 10 & 0.43 \\
\hline Iceland & 1 & 0.38 & 3 & 0.13 \\
\hline India & 8 & 3.05 & 65 & 2.82 \\
\hline Indonesia & 2 & 0.76 & 20 & 0.87 \\
\hline Ireland & 3 & 1.15 & 24 & 1.04 \\
\hline Israel & 4 & 1.53 & 35 & 1.52 \\
\hline Italy & 6 & 2.29 & 60 & 2.6 \\
\hline Japan & 49 & 18.70 & 437 & 18.93 \\
\hline Jordan & 1 & 0.38 & 8 & 0.35 \\
\hline Korea & 6 & 2.29 & 46 & 1.99 \\
\hline Luxembourg & 1 & 0.38 & 7 & 0.3 \\
\hline Malaysia & 6 & 2.29 & 60 & 2.6 \\
\hline Mexico & 2 & 0.76 & 20 & 0.87 \\
\hline Netherlands & 3 & 1.15 & 20 & 0.87 \\
\hline Norway & 1 & 0.38 & 10 & 0.43 \\
\hline Poland & 2 & 0.76 & 19 & 0.82 \\
\hline Portugal & 3 & 1.15 & 30 & 1.3 \\
\hline Russia & 1 & 0.38 & 7 & 0.3 \\
\hline Saudi Arabia & 5 & 1.91 & 48 & 2.08 \\
\hline Singapore & 3 & 1.15 & 30 & 1.3 \\
\hline South Africa & 5 & 1.91 & 49 & 2.12 \\
\hline Spain & 6 & 2.29 & 52 & 2.25 \\
\hline Sweden & 3 & 1.15 & 30 & 1.3 \\
\hline Switzerland & 4 & 1.53 & 32 & 1.39 \\
\hline Taiwan & 12 & 4.58 & 118 & 5.11 \\
\hline Thailand & 6 & 2.29 & 57 & 2.47 \\
\hline Turkey & 5 & 1.91 & 39 & 1.69 \\
\hline United Arab Emirates & 1 & 0.38 & 10 & 0.43 \\
\hline United Kingdom & 8 & 3.05 & 62 & 2.69 \\
\hline USA & 43 & 16.41 & 370 & 16.02 \\
\hline Total & 262 & 100.00 & 2,309 & 100.00 \\
\hline
\end{tabular}


Table 2: Descriptive Statistics

\begin{tabular}{|c|c|c|c|c|c|c|c|}
\hline & & $\mathbf{N}$ & Mean & Median & St.Dev. & 1 Pctile & 99 Pctile \\
\hline \multicolumn{8}{|c|}{ Panel A: Dependent Variables (2005-2014) } \\
\hline Ln (Z-Score) & Minus the ln transformation of a bank's Z-Score & 2305 & -5.121 & -4.917 & 0.749 & -7.829 & -4.568 \\
\hline Equity Ratio & Book value of bank's equity divided by its assets (\%) & 2305 & 7.207 & 6.568 & 2.920 & 1.915 & 15.736 \\
\hline ROA Volatility & $\begin{array}{l}\text { Absolute yearly deviation from the average ROA over } \\
\text { the sample period }(\%)\end{array}$ & 2305 & 0.627 & 0.627 & 1.239 & -2.915 & 2.833 \\
\hline $\mathrm{ROA}$ & Net income divided by total assets (\%) & 2305 & 0.400 & 0.187 & 0.918 & 0.003 & 3.211 \\
\hline Equity Volatility & Volatility of daily stock returns $(\%)$ & 2309 & 2.315 & 1.940 & 1.417 & 0.727 & 7.798 \\
\hline VaR & $\begin{array}{l}\text { Bank daily return equal to the } 5^{\text {th }} \text { percentile of the } \\
\text { yearly distribution }(\%)\end{array}$ & 2309 & 3.518 & 2.942 & 2.120 & 0.988 & 11.196 \\
\hline ES & $\begin{array}{l}\text { Average bank daily returns below the } 5^{\text {th }} \text { percentile of } \\
\text { the yearly distribution }(\%)\end{array}$ & 2309 & 5.000 & 4.169 & 3.146 & 1.541 & 17.252 \\
\hline \multicolumn{8}{|c|}{ Panel B: Bank Characteristics (2004-2013) } \\
\hline $\begin{array}{l}\text { Board } \\
\text { Independence }\end{array}$ & Independent directors divided by total directors (\%) & 2309 & 47.015 & 50.000 & 30.070 & 0.000 & 100.000 \\
\hline Size & Log transformation of bank total assets (in thousands of US\$) & 2309 & 18.381 & 18.082 & 1.335 & 16.426 & 21.633 \\
\hline Book-to-Market & Book value of equity divided by the market value of equity & 2309 & 1.189 & 0.857 & 1.599 & 0.175 & 5.832 \\
\hline Deposits & Customer deposits divided by total debts (\%) & 2309 & 73.487 & 0.787 & 0.160 & 0.989 & 0.197 \\
\hline Loans & Total loans divided by total assets (\%) & 2309 & 57.839 & 0.604 & 0.141 & 0.826 & 0.137 \\
\hline Lending Risk & Loan loss reserves divided by total loans (\%) & 2309 & 2.669 & 1.681 & 9.344 & 0.000 & 11.414 \\
\hline Board Size & Log transformation of the number of board members & 2309 & 2.531 & 2.565 & 0.326 & 1.792 & 3.332 \\
\hline CEO Power & $\begin{array}{l}\text { The sum of three dummy variables: a dummy equal to } 1 \text { if the } \\
\text { CEO is also Chairman of the Board; a dummy equal to one if } \\
\text { the CEO has been internally appointed; a dummy equal to one } \\
\text { if the CEO is the only non-independent director in the board. }\end{array}$ & 2278 & 1.199 & 1.000 & 0.692 & 0.000 & 3.000 \\
\hline $\begin{array}{l}\text { Institutional } \\
\text { Shareholders }\end{array}$ & $\begin{array}{l}\text { Shares owned by institutional shareholders divided by total } \\
\text { shares }(\%)\end{array}$ & 2233 & 31.016 & 24.260 & 24.244 & 0.082 & 94.410 \\
\hline \multicolumn{8}{|c|}{ Panel C: Country Controls (2005-2014) } \\
\hline Corruption & $\begin{array}{l}\text { Score defined as minus the Heritage Foundation Freedom } \\
\text { from Corruption Index, with larger values denoting more } \\
\text { corrupted countries }\end{array}$ & 2309 & -65.071 & -71.000 & 18.324 & -94.000 & -28.000 \\
\hline $\begin{array}{l}\text { Supervisory } \\
\text { Strength }\end{array}$ & $\begin{array}{l}\text { From Barth et al. (2001) and following surveys. It assesses the } \\
\text { general strength of the supervisory agency at the country level. } \\
\text { The index ranges from zero to } 14 \text { and is based on the } \\
\text { following questions: (1) Does the supervisory agency have the } \\
\text { right to meet with external auditors to discuss reports without } \\
\text { the approval of the bank? (2) Are the auditors required to } \\
\text { communicate misconduct by managers/directors to the } \\
\text { supervisory agency? (3) Can legal action against external } \\
\text { auditors be taken by supervisors for negligence? (4) Can } \\
\text { supervisors force banks to change the internal organizational } \\
\text { structure? (5) Are off-balance sheet items disclosed to } \\
\text { supervisors? (6) Can the supervisory agency order } \\
\text { directors/management to constitute provisions to cover } \\
\text { actual/potential losses? (7) Can the supervisory agency } \\
\text { suspend director's decisions to distribute: (a) Dividends? (b) } \\
\text { Bonuses? (c) Management fees? (8) Can the supervisory } \\
\text { agency supersede bank shareholder rights and declare a bank } \\
\text { insolvent? (9) Does banking law allow the supervisory agency } \\
\text { to suspend some or all ownership rights of a problem bank? } \\
\text { (10) Regarding bank restructuring and reorganization, can the } \\
\text { supervisory agency or any other government agency do the } \\
\text { following: (a) Suspend shareholder rights? (b) Remove and } \\
\text { replace management? (c) Remove and replace directors? }\end{array}$ & 2309 & 11.248 & 12.000 & 1.974 & 5.000 & 14.000 \\
\hline No Basel I & A dummy equal to one if a country has abandoned Basel I & 2309 & 0.617 & 1.000 & 0.486 & 0.000 & 1.000 \\
\hline Concentration & $\begin{array}{l}\text { Log transformation of the Herfindhal index of asset } \\
\text { concentration in the domestic banking market }\end{array}$ & 2309 & -2.679 & -2.700 & 0.712 & -4.038 & -1.169 \\
\hline GDP Growth & Annual real growth rate of the domestic GDP $(\%)$ & 2309 & 2.348 & 2.200 & 3.369 & -5.500 & 10.600 \\
\hline Public Debt & $\begin{array}{l}\text { Ratio between the volume of debt from the public sector and } \\
\text { country GDP }(\%)\end{array}$ & 2309 & 89.462 & 66.800 & 65.756 & 4.600 & 242.200 \\
\hline Econ_Dev & Log transformation of the GDP per capita in US dollars & 2309 & 10.189 & 10.476 & 0.896 & 7.155 & 11.368 \\
\hline $\begin{array}{l}\text { Shareholder } \\
\text { Protection }\end{array}$ & $\begin{array}{l}\text { Country index measuring the strength of minority shareholder } \\
\text { protection from Doing Business by the WorldBank }\end{array}$ & 2309 & 6.665 & 7.000 & 1.472 & 3.000 & 9.300 \\
\hline Market Volatility & $\begin{array}{l}\text { Volatility of the domestic stock market based on Datastream } \\
\text { Stock Market Indexes (\%) }\end{array}$ & 2309 & 1.418 & 1.275 & 0.623 & 0.629 & 3.564 \\
\hline
\end{tabular}


Table 3: Does the Impact of Board Independence on Bank Risk Change Post-2009?

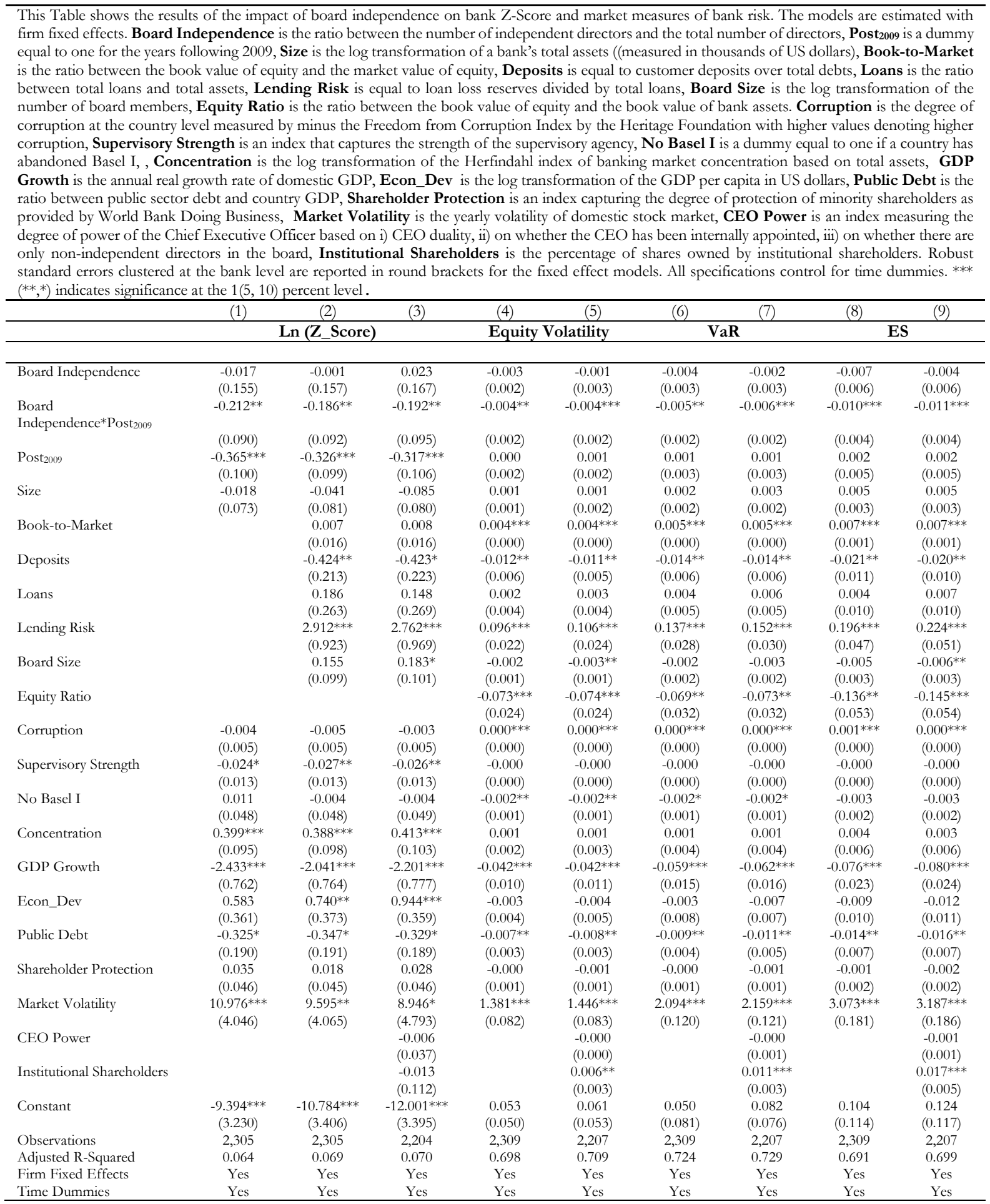


Table 4: Does the Impact of Board Independence on Z-Score Components Change Post-2009?

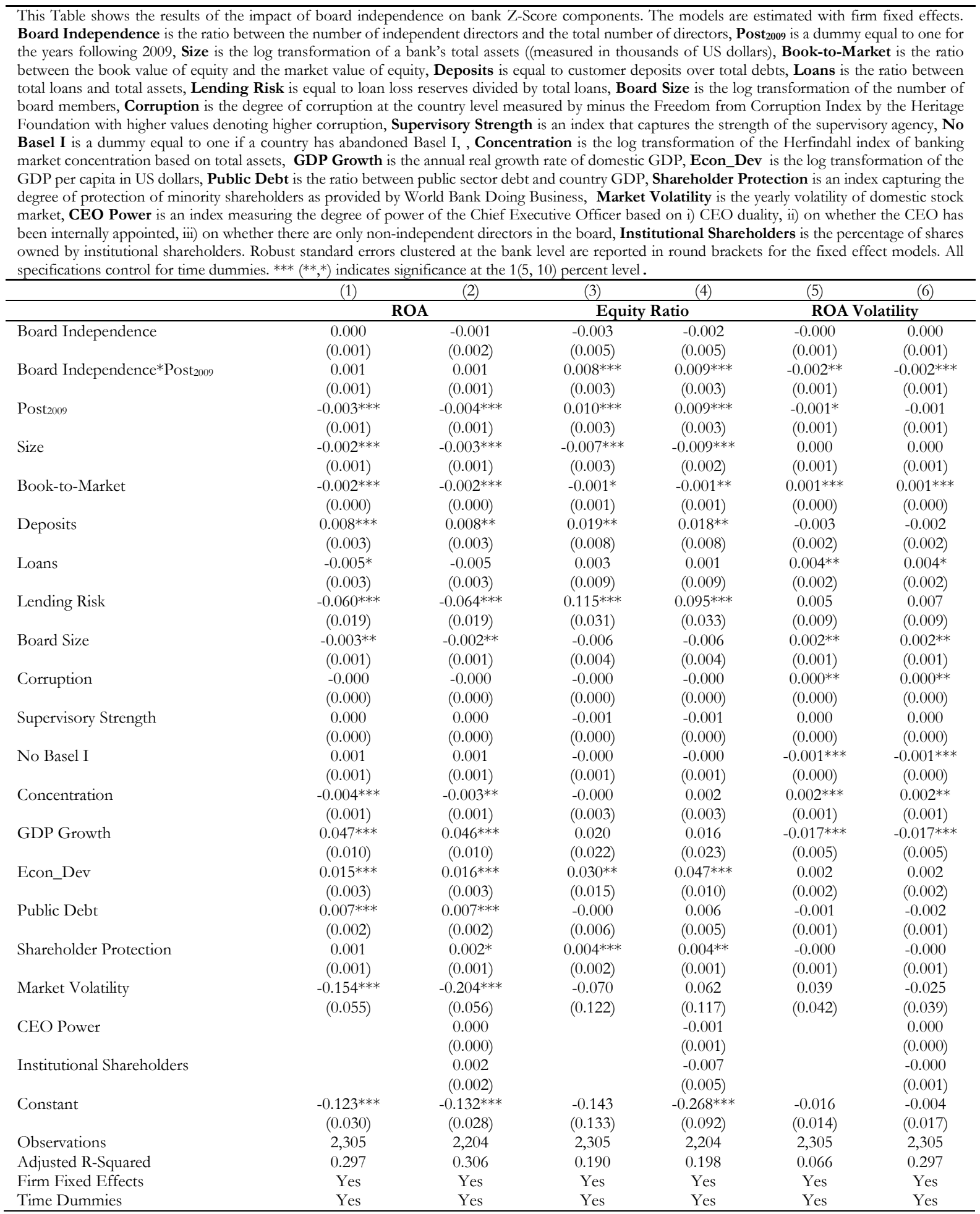


Table 5: Impact of Independent Directors on Taxpayers: Bank Public Recapitalizations

\begin{tabular}{|c|c|c|c|c|c|}
\hline \multicolumn{6}{|c|}{$\begin{array}{l}\text { This Table shows the impact of board independence on bank public recapitalizations required by the global financial crisis. In columns (1) and } \\
\text { (2) we estimate a logit model where the dependent variable is a dummy equal one if a bank has received public funds during the global crisis. In } \\
\text { remaining columns we estimate Tobit models where the dependent variable is the ratio between the amount of public funds received after } 2006 \\
\text { and bank total assets at the end of } 2006 \text {. Board Independence is the ratio between the number of independent directors and the total number } \\
\text { of directors, Size is the log transformation of the bank total assets (measured in thousands of US dollars), ROA is the ratio between net income } \\
\text { and total assets, Book-to-Market is the ratio between book value of equity and market value of equity, Customer Deposits is the ratio between } \\
\text { customer deposits and bank total funding, Loans is the ratio between total loans and total assets, Lending Risk is equal to loan loss reserves } \\
\text { divided by total loans, Equity is the ratio between bank book equity and total assets, MES is the average bank daily stock return when the market } \\
\text { is the lowest } 5 \text { percent of the yearly distribution, IPP is the fair insurance premium described in section } 2.1 \text {, Board Size is the log transformation } \\
\text { of the number of board members, CEO Power is an index measuring the degree of power of the Chief Executive Officer based on i) CEO } \\
\text { duality, ii) on whether the CEO has been internally appointed, iii) on whether is the only non-independent director in the board, Institutional } \\
\text { Shareholders is the percentage of shares owned by institutional shareholders. Robust t statistics are reported in round brackets for the fixed } \\
\text { effect models. All specifications control for time dummies. } * * * ~(* *, *) \text { indicates significance at the } 1(5,10) \text { percent level. }\end{array}$} \\
\hline & $(1)$ & $(2)$ & (3) & $(4)$ & $(5)$ \\
\hline Board Independence & 2.136 & $3.919 * * *$ & $0.036^{* *}$ & $0.047 * *$ & \\
\hline & $(1.306)$ & $(1.423)$ & $(0.018)$ & $(0.021)$ & $(0.025)$ \\
\hline Size & $0.556^{* *}$ & $0.707 * *$ & $0.007^{* *}$ & $0.007^{*}$ & 0.001 \\
\hline & $(0.247)$ & $(0.300)$ & $(0.003)$ & $(0.004)$ & $(0.004)$ \\
\hline ROA & -1.106 & -22.656 & 0.076 & -0.087 & 2.040 \\
\hline & $(55.571)$ & $(62.035)$ & $(0.958)$ & $(0.964)$ & $(1.469)$ \\
\hline Book-to-Market & $-3.390^{* * *}$ & $-3.875^{* * *}$ & $-0.054^{* * *}$ & $-0.061^{* * *}$ & -0.005 \\
\hline & $(1.084)$ & $(1.337)$ & $(0.017)$ & $(0.020)$ & $(0.037)$ \\
\hline Customer Deposits & -1.153 & -0.441 & -0.010 & -0.002 & 0.015 \\
\hline & $(1.444)$ & $(2.213)$ & $(0.020)$ & $(0.024)$ & $(0.028)$ \\
\hline Loans & $5.406^{* * *}$ & $8.179 * * *$ & $0.125^{* * *}$ & $0.146^{* * *}$ & 0.043 \\
\hline & $(1.842)$ & $(2.226)$ & $(0.045)$ & $(0.051)$ & $(0.026)$ \\
\hline Lending Risk & -4.730 & -28.109 & -0.107 & -0.631 & 0.308 \\
\hline & $(15.299)$ & $(35.997)$ & $(0.315)$ & $(0.505)$ & $(0.903)$ \\
\hline Equity & -3.700 & -5.964 & -0.174 & -0.106 & -0.025 \\
\hline & $(12.024)$ & $(15.160)$ & $(0.181)$ & $(0.186)$ & $(0.206)$ \\
\hline MES & $37.004 *$ & $38.606^{*}$ & 0.770 & 0.543 & 1.944 \\
\hline & $(19.680)$ & $(23.219)$ & $(0.518)$ & $(0.450)$ & $(1.663)$ \\
\hline IPP & $4.198 * * *$ & $5.076^{* * *}$ & $0.052^{* * *}$ & $0.071 * * *$ & -0.022 \\
\hline & $(1.454)$ & $(1.897)$ & $(0.018)$ & $(0.023)$ & $(0.055)$ \\
\hline Board Size & 0.291 & 0.613 & -0.006 & -0.002 & 0.022 \\
\hline & $(0.724)$ & $(0.821)$ & $(0.010)$ & $(0.010)$ & $(0.017)$ \\
\hline CEO Power & & -0.098 & & -0.004 & 0.005 \\
\hline & & $(0.571)$ & & $(0.006)$ & $(0.008)$ \\
\hline \multirow[t]{2}{*}{ Institutional Shareholders } & & 1.408 & & $0.059 *$ & -0.006 \\
\hline & & $(1.535)$ & & $(0.034)$ & $(0.025)$ \\
\hline \multirow[t]{2}{*}{ Constant } & $-17.090^{* * *}$ & $-24.058^{* * *}$ & $-0.255^{* * *}$ & $-0.288^{* * *}$ & $-0.194 * *$ \\
\hline & $(5.575)$ & $(6.638)$ & $(0.076)$ & $(0.084)$ & $(0.071)$ \\
\hline Observations & 240 & 222 & 240 & 222 & 40 \\
\hline Pseudo R-Squared & 0.440 & 0.516 & & & \\
\hline Country & Full Sample & Full Sample & Full Sample & Full Sample & Only US \\
\hline Country Fixed Effects & Yes & Yes & Yes & Yes & \\
\hline
\end{tabular}


Table 6: Does the Impact of Board Independence on Bank Risk Change Post-2009?

\section{Controlling for the Bailout Effect}

\begin{tabular}{|c|c|c|c|c|c|c|c|c|}
\hline \multicolumn{9}{|c|}{ 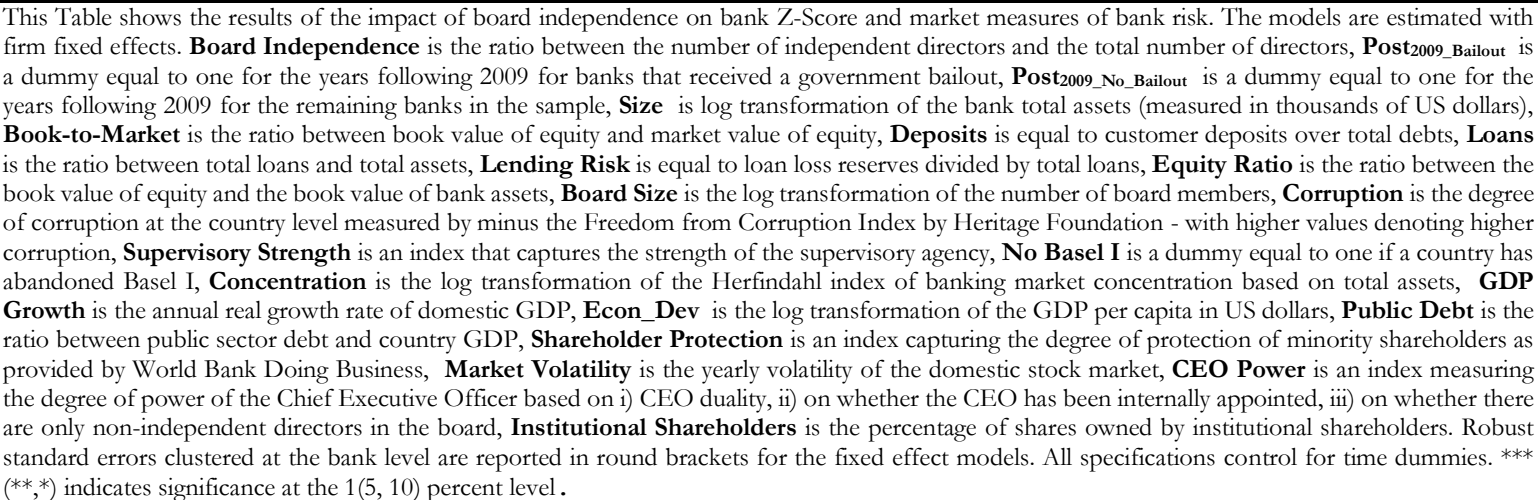 } \\
\hline & $(1)$ & $(2)$ & (3) & $(4)$ & (5) & (6) & $(7)$ & $(8)$ \\
\hline & \multicolumn{2}{|c|}{$\operatorname{Ln}(\mathrm{Z}$ Score) } & \multicolumn{2}{|c|}{ Equity Volatility } & \multicolumn{2}{|c|}{ VaR } & \multicolumn{2}{|c|}{ ES } \\
\hline Board Independence & $\begin{array}{l}0.033 \\
(0.158)\end{array}$ & $\begin{array}{l}0.061 \\
(0.169)\end{array}$ & $\begin{array}{l}-0.001 \\
(0.003)\end{array}$ & $\begin{array}{l}-0.000 \\
(0.003)\end{array}$ & $\begin{array}{c}-0.002 \\
(0.004)\end{array}$ & $\begin{array}{l}-0.000 \\
(0.004)\end{array}$ & $\begin{array}{l}-0.004 \\
(0.006)\end{array}$ & $\begin{array}{l}-0.001 \\
(0.006)\end{array}$ \\
\hline Board Independence*Post2009_Bailout & $\begin{array}{l}-0.427 * * * \\
(0.153)\end{array}$ & $\begin{array}{l}-0.448^{* * *} \\
(0.164)\end{array}$ & $\begin{array}{l}-0.014^{* * *} \\
(0.004)\end{array}$ & $\begin{array}{l}-0.016^{* * *} \\
(0.004)\end{array}$ & $\begin{array}{l}-0.021^{* * *} \\
(0.005)\end{array}$ & $\begin{array}{l}-0.023^{* * *} \\
(0.005)\end{array}$ & $\begin{array}{l}-0.032^{* * *} \\
(0.008)\end{array}$ & $\begin{array}{l}-0.036^{* * *} \\
(0.009)\end{array}$ \\
\hline Board & -0.148 & -0.149 & 0.001 & 0.000 & 0.000 & -0.000 & -0.001 & -0.001 \\
\hline Independence*Post2009_No_Bailout & $(0.118)$ & $(0.121)$ & $(0.001)$ & $(0.001)$ & $(0.002)$ & $(0.002)$ & $(0.003)$ & $(0.003)$ \\
\hline Post2009_Bailout & $\begin{array}{l}-0.245^{* *} \\
(0.113)\end{array}$ & $\begin{array}{l}-0.235^{*} \\
(0.120)\end{array}$ & $\begin{array}{l}-0.000 \\
(0.003)\end{array}$ & $\begin{array}{l}0.000 \\
(0.003)\end{array}$ & $\begin{array}{l}0.001 \\
(0.004)\end{array}$ & $\begin{array}{l}0.002 \\
(0.004)\end{array}$ & $\begin{array}{l}0.001 \\
(0.006)\end{array}$ & $\begin{array}{l}0.002 \\
(0.007)\end{array}$ \\
\hline Post2009_No_Bailout & $\begin{array}{l}-0.335^{* * *} \\
(0.102)\end{array}$ & $\begin{array}{l}-0.318^{* * *} \\
(0.109)\end{array}$ & $\begin{array}{l}0.001 \\
(0.002)\end{array}$ & $\begin{array}{l}0.001 \\
(0.002)\end{array}$ & $\begin{array}{l}0.002 \\
(0.003)\end{array}$ & $\begin{array}{l}0.001 \\
(0.003)\end{array}$ & $\begin{array}{l}0.004 \\
(0.005)\end{array}$ & $\begin{array}{l}0.004 \\
(0.005)\end{array}$ \\
\hline Size & $\begin{array}{l}-0.043 \\
(0.081)\end{array}$ & $\begin{array}{l}-0.089 \\
(0.081)\end{array}$ & $\begin{array}{l}0.001 \\
(0.001)\end{array}$ & $\begin{array}{l}0.001 \\
(0.002)\end{array}$ & $\begin{array}{l}0.002 \\
(0.002)\end{array}$ & $\begin{array}{l}0.002 \\
(0.002)\end{array}$ & $\begin{array}{l}0.004 \\
(0.003)\end{array}$ & $\begin{array}{l}0.004 \\
(0.003)\end{array}$ \\
\hline Book-to-Market & $\begin{array}{l}0.004 \\
(0.017)\end{array}$ & $\begin{array}{l}0.005 \\
(0.017)\end{array}$ & $\begin{array}{l}0.004 * * * \\
(0.000)\end{array}$ & $\begin{array}{l}0.004 * * * \\
(0.000)\end{array}$ & $\begin{array}{l}0.005^{* * *} \\
(0.000)\end{array}$ & $\begin{array}{l}0.005^{* * *} \\
(0.000)\end{array}$ & $\begin{array}{l}0.007 * * * \\
(0.001)\end{array}$ & $\begin{array}{l}0.007 * * * \\
(0.001)\end{array}$ \\
\hline Deposits & $\begin{array}{l}-0.426^{* *} \\
(0.213)\end{array}$ & $\begin{array}{l}-0.423^{*} \\
(0.223)\end{array}$ & $\begin{array}{l}-0.012 * * \\
(0.005)\end{array}$ & $\begin{array}{l}-0.011^{* *} \\
(0.005)\end{array}$ & $\begin{array}{l}-0.014^{* *} \\
(0.006)\end{array}$ & $\begin{array}{l}-0.014^{* *} \\
(0.006)\end{array}$ & $\begin{array}{l}-0.021 * \\
(0.011)\end{array}$ & $\begin{array}{l}-0.020^{* *} \\
(0.010)\end{array}$ \\
\hline Loans & $\begin{array}{l}0.179 \\
(0.267)\end{array}$ & $\begin{array}{l}0.136 \\
(0.273)\end{array}$ & $\begin{array}{l}-0.001 \\
(0.004)\end{array}$ & $\begin{array}{l}0.001 \\
(0.004)\end{array}$ & $\begin{array}{l}0.001 \\
(0.006)\end{array}$ & $\begin{array}{l}0.003 \\
(0.006)\end{array}$ & $\begin{array}{l}-0.002 \\
(0.011)\end{array}$ & $\begin{array}{l}0.001 \\
(0.011)\end{array}$ \\
\hline Lending Risk & $\begin{array}{l}2.827 * * * \\
(0.900)\end{array}$ & $\begin{array}{l}2.718^{* * *} \\
(0.945)\end{array}$ & $\begin{array}{l}0.104 * * * \\
(0.024)\end{array}$ & $\begin{array}{l}0.116^{* * *} \\
(0.025)\end{array}$ & $\begin{array}{l}0.145^{* * *} \\
(0.029)\end{array}$ & $\begin{array}{l}0.161 * * * \\
(0.032)\end{array}$ & $\begin{array}{l}0.214^{* * *} \\
(0.050)\end{array}$ & $\begin{array}{l}0.244 * * * \\
(0.054)\end{array}$ \\
\hline Board Size & $\begin{array}{l}0.167^{*} \\
(0.099)\end{array}$ & $\begin{array}{l}0.194 * \\
(0.101)\end{array}$ & $\begin{array}{l}-0.002 \\
(0.001)\end{array}$ & $\begin{array}{l}-0.002 * \\
(0.001)\end{array}$ & $\begin{array}{l}-0.001 \\
(0.002)\end{array}$ & $\begin{array}{l}-0.002 \\
(0.002)\end{array}$ & $\begin{array}{l}-0.004 \\
(0.003)\end{array}$ & $\begin{array}{l}-0.005^{*} \\
(0.003)\end{array}$ \\
\hline Equity Ratio & & & $\begin{array}{l}-0.062 * * \\
(0.025)\end{array}$ & $\begin{array}{l}-0.063^{* *} \\
(0.025)\end{array}$ & $\begin{array}{l}-0.057^{*} \\
(0.034)\end{array}$ & $\begin{array}{l}-0.061^{*} \\
(0.034)\end{array}$ & $\begin{array}{l}-0.111^{* *} \\
(0.055)\end{array}$ & $\begin{array}{l}-0.121^{* *} \\
(0.056)\end{array}$ \\
\hline Corruption & $\begin{array}{l}-0.005 \\
(0.005)\end{array}$ & $\begin{array}{l}-0.003 \\
(0.005)\end{array}$ & $\begin{array}{l}0.000 * * * \\
(0.000)\end{array}$ & $\begin{array}{l}0.000 * * * \\
(0.000)\end{array}$ & $\begin{array}{l}0.001^{* * *} \\
(0.000)\end{array}$ & $\begin{array}{l}0.000^{* * *} \\
(0.000)\end{array}$ & $\begin{array}{l}0.001 * * * \\
(0.000)\end{array}$ & $\begin{array}{l}0.001 * * * \\
(0.000)\end{array}$ \\
\hline Supervisory Strength & $\begin{array}{l}-0.026^{* *} \\
(0.013)\end{array}$ & $\begin{array}{c}-0.025^{*} \\
(0.013)\end{array}$ & $\begin{array}{l}-0.000 \\
(0.000)\end{array}$ & $\begin{array}{l}-0.000 \\
(0.000)\end{array}$ & $\begin{array}{l}-0.000 \\
(0.000)\end{array}$ & $\begin{array}{l}-0.000 \\
(0.000)\end{array}$ & $\begin{array}{l}-0.000 \\
(0.000)\end{array}$ & $\begin{array}{l}-0.000 \\
(0.000)\end{array}$ \\
\hline No Basel I & $\begin{array}{l}-0.011 \\
(0.048)\end{array}$ & $\begin{array}{l}-0.012 \\
(0.049)\end{array}$ & $\begin{array}{l}-0.002^{* *} \\
(0.001)\end{array}$ & $\begin{array}{l}-0.003^{* * *} \\
(0.001)\end{array}$ & $\begin{array}{l}-0.003^{* *} \\
(0.001)\end{array}$ & $\begin{array}{l}-0.003^{* *} \\
(0.001)\end{array}$ & $\begin{array}{l}-0.004^{*} \\
(0.002)\end{array}$ & $\begin{array}{l}-0.004^{* *} \\
(0.002)\end{array}$ \\
\hline Concentration & $\begin{array}{l}0.400 * * * \\
(0.099)\end{array}$ & $\begin{array}{l}0.418^{* * *} \\
(0.103)\end{array}$ & $\begin{array}{l}0.002 \\
(0.003)\end{array}$ & $\begin{array}{l}0.002 \\
(0.003)\end{array}$ & $\begin{array}{l}0.003 \\
(0.004)\end{array}$ & $\begin{array}{l}0.002 \\
(0.004)\end{array}$ & $\begin{array}{l}0.005 \\
(0.006)\end{array}$ & $\begin{array}{l}0.004 \\
(0.006)\end{array}$ \\
\hline GDP Growth & $\begin{array}{l}-1.894 * * \\
(0.767)\end{array}$ & $\begin{array}{l}-2.062^{* * *} \\
(0.778)\end{array}$ & $\begin{array}{l}-0.037 * * * \\
(0.010)\end{array}$ & $\begin{array}{l}-0.037 * * * \\
(0.010)\end{array}$ & $\begin{array}{l}-0.052^{* * *} \\
(0.015)\end{array}$ & $\begin{array}{l}-0.055^{* * *} \\
(0.015)\end{array}$ & $\begin{array}{l}-0.066^{* * *} \\
(0.023)\end{array}$ & $\begin{array}{l}-0.070^{* * *} \\
(0.024)\end{array}$ \\
\hline Econ_Dev & $\begin{array}{l}0.831 * * \\
(0.356)\end{array}$ & $\begin{array}{l}1.020^{* * *} \\
(0.354)\end{array}$ & $\begin{array}{l}-0.000 \\
(0.004)\end{array}$ & $\begin{array}{l}0.000 \\
(0.005)\end{array}$ & $\begin{array}{l}0.002 \\
(0.007)\end{array}$ & $\begin{array}{l}-0.001 \\
(0.007)\end{array}$ & $\begin{array}{l}-0.003 \\
(0.010)\end{array}$ & $\begin{array}{l}-0.003 \\
(0.011)\end{array}$ \\
\hline Public Debt & $\begin{array}{l}-0.351^{*} \\
(0.191)\end{array}$ & $\begin{array}{l}-0.335^{*} \\
(0.191)\end{array}$ & $\begin{array}{l}-0.005^{*} \\
(0.003)\end{array}$ & $\begin{array}{l}-0.006^{*} \\
(0.004)\end{array}$ & $\begin{array}{l}-0.007 \\
(0.004)\end{array}$ & $\begin{array}{l}-0.009^{*} \\
(0.005)\end{array}$ & $\begin{array}{l}-0.009 \\
(0.007)\end{array}$ & $\begin{array}{l}-0.011 \\
(0.008)\end{array}$ \\
\hline Shareholder Protection & $\begin{array}{l}0.013 \\
(0.046)\end{array}$ & $\begin{array}{l}0.022 \\
(0.047)\end{array}$ & $\begin{array}{l}-0.000 \\
(0.001)\end{array}$ & $\begin{array}{l}-0.001 \\
(0.001)\end{array}$ & $\begin{array}{l}-0.001 \\
(0.001)\end{array}$ & $\begin{array}{l}-0.001^{*} \\
(0.001)\end{array}$ & $\begin{array}{l}-0.002 \\
(0.002)\end{array}$ & $\begin{array}{l}-0.003 \\
(0.002)\end{array}$ \\
\hline Market Volatility & $\begin{array}{l}8.822 * * \\
(4.102)\end{array}$ & $\begin{array}{l}8.070^{*} \\
(4.851)\end{array}$ & $\begin{array}{l}1.365 * * * \\
(0.080)\end{array}$ & $\begin{array}{l}1.428^{* * *} \\
(0.081)\end{array}$ & $\begin{array}{l}2.064 * * * \\
(0.118)\end{array}$ & $\begin{array}{l}2.122^{* * *} \\
(0.121)\end{array}$ & $\begin{array}{l}3.040^{* * * *} \\
(0.179)\end{array}$ & $\begin{array}{l}3.144 * * * \\
(0.185)\end{array}$ \\
\hline CEO Power & & $\begin{array}{l}-0.003 \\
(0.037)\end{array}$ & & $\begin{array}{l}-0.000 \\
(0.001)\end{array}$ & & $\begin{array}{l}-0.000 \\
(0.001)\end{array}$ & & $\begin{array}{l}-0.001 \\
(0.001)\end{array}$ \\
\hline Institutional Shareholders & & $\begin{array}{l}-0.012 \\
(0.112)\end{array}$ & & $\begin{array}{l}0.007 * * * \\
(0.003)\end{array}$ & & $\begin{array}{l}0.011^{* * *} \\
(0.003)\end{array}$ & & $\begin{array}{l}0.018^{* * *} \\
(0.005)\end{array}$ \\
\hline Constant & $\begin{array}{l}-11.630 * * * \\
(3.284)\end{array}$ & $\begin{array}{l}-12.677^{* * * *} \\
(3.357)\end{array}$ & $\begin{array}{l}0.038 \\
(0.048)\end{array}$ & $\begin{array}{l}0.034 \\
(0.055)\end{array}$ & $\begin{array}{l}0.019 \\
(0.078)\end{array}$ & $\begin{array}{l}0.041 \\
(0.077)\end{array}$ & $\begin{array}{l}0.071 \\
(0.108)\end{array}$ & $\begin{array}{l}0.064 \\
(0.120)\end{array}$ \\
\hline Observations & 2,305 & 2,204 & 2,309 & 2,207 & 2,309 & 2,207 & 2,309 & 2,207 \\
\hline Adjusted R-Squared & 0.070 & 0.070 & 0.706 & 0.718 & 0.729 & 0.735 & 0.699 & 0.707 \\
\hline Firm Fixed Effects & Yes & Yes & Yes & Yes & Yes & Yes & Yes & Yes \\
\hline Time Dummies & Yes & Yes & Yes & Yes & Yes & Yes & Yes & Yes \\
\hline
\end{tabular}


Table 7: Does the Impact of Board Independence on Z-Score Components Change Post-2009?

Controlling for the Bailout Effect

This Table shows the results of the impact of board independence on the components of a bank Z-Score. The models are estimated with firm fixed effects. Board Independence is the ratio between the number of independent directors and the total number of directors, Post $2009 \_$Bailout is a dummy equal to one for the years following 2009 for banks that received a government bailout, Post2009_No_Bailout is a dummy equal to one for the years following 2009 for the remaining banks in the sample, Size is the log transformation of the bank total assets (measured in thousands of US dollars), Size is the log transformation of a bank's total assets (measured in thousands of US dollars), Book-to-Market is the ratio between the book value of equity and the market value of equity, Deposits is equal to customer deposits over total debts, Loans is the ratio between total loans and total assets, Lending Risk is equal to loan loss reserves divided by total loans, Board Size is the log transformation of the number of board members, Corruption is the degree of corruption at the country level measured by minus the Freedom from Corruption Index by Heritage Foundation with higher values denoting higher corruption, Supervisory Strength is an index that captures the strength of the supervisory agency, No Basel I is a dummy equal to one if a country has abandoned Basel I, , Concentration is $\log$ transformation of the Herfindahl index of banking market concentration based on total assets, GDP Growth is the annual real growth rate of domestic GDP, Econ_Dev is the log transformation of the GDP per capita in US dollars, Public Debt is the ratio between public sector debt and country GDP, Shareholder Protection is an index capturing the degree of protection of minority shareholders as provided by World Bank Doing Business, Market Volatility is the yearly volatility of domestic stock market, CEO Power is an index measuring the degree of power of the Chief Executive Officer based on i) CEO duality, ii) on whether the CEO has been internally appointed, iii) on whether there are only non-independent directors in the board, Institutional Shareholders is the percentage of shares owned by institutional shareholders. Robust standard errors clustered at the bank level are reported in round brackets for the fixed effect models. All specifications control for time dummies. ${ }^{* * *}(* *, *)$ indicates significance at the $1(5,10)$ percent level .

\begin{tabular}{|c|c|c|c|c|c|c|}
\hline & $(1)$ & (2) & (3) & (4) & $(5)$ & $(6)$ \\
\hline & \multicolumn{2}{|c|}{ ROA } & \multicolumn{2}{|c|}{ Equity Ratio } & \multicolumn{2}{|c|}{ ROA Volatility } \\
\hline \multirow[t]{2}{*}{ Board Independence } & -0.000 & -0.002 & -0.003 & -0.003 & -0.000 & 0.000 \\
\hline & $(0.002)$ & $(0.002)$ & $(0.005)$ & $(0.005)$ & $(0.001)$ & $(0.001)$ \\
\hline \multirow[t]{2}{*}{ Board Independence*Post2009_Bailout } & 0.003 & 0.004 & 0.012 & 0.013 & $-0.004^{* *}$ & $-0.005^{* * *}$ \\
\hline & $(0.003)$ & $(0.003)$ & $(0.008)$ & $(0.008)$ & $(0.002)$ & $(0.002)$ \\
\hline \multirow[t]{2}{*}{ Board Independence*Post2009_No_Bailout } & -0.001 & -0.000 & $0.006^{* *}$ & $0.007^{* *}$ & 0.000 & -0.000 \\
\hline & $(0.001)$ & $(0.001)$ & $(0.003)$ & $(0.003)$ & $(0.001)$ & $(0.001)$ \\
\hline \multirow[t]{2}{*}{ Post2009_Bailouts } & $-0.003 * *$ & $-0.004^{* *}$ & $0.011^{* *}$ & $0.009 * *$ & $-0.002^{* * *}$ & -0.001 \\
\hline & $(0.001)$ & $(0.001)$ & $(0.004)$ & $(0.004)$ & $(0.001)$ & $(0.001)$ \\
\hline \multirow[t]{2}{*}{ Post2009_No_Bailout } & $-0.004 * * *$ & $-0.004 * * *$ & $0.010^{* * *}$ & $0.008^{* * *}$ & -0.001 & -0.000 \\
\hline & $(0.001)$ & $(0.001)$ & $(0.003)$ & $(0.003)$ & $(0.001)$ & $(0.001)$ \\
\hline \multirow[t]{2}{*}{ Size } & $-0.002 * *$ & $-0.002 * * *$ & $-0.007 * *$ & $-0.009 * * *$ & -0.000 & -0.000 \\
\hline & $(0.001)$ & $(0.001)$ & $(0.003)$ & $(0.002)$ & $(0.001)$ & $(0.001)$ \\
\hline \multirow[t]{2}{*}{ Book-to-Market } & $-0.002^{* * *}$ & $-0.002^{* * *}$ & $-0.001 *$ & $-0.002^{* *}$ & $0.001 * * *$ & $0.001 * * *$ \\
\hline & $(0.000)$ & $(0.000)$ & $(0.001)$ & $(0.001)$ & $(0.000)$ & $(0.000)$ \\
\hline \multirow[t]{2}{*}{ Deposits } & $0.008^{* * *}$ & $0.007^{* *}$ & $0.018^{* *}$ & $0.018^{* *}$ & -0.003 & -0.002 \\
\hline & $(0.003)$ & $(0.003)$ & $(0.008)$ & $(0.008)$ & $(0.002)$ & $(0.002)$ \\
\hline \multirow[t]{2}{*}{ Loans } & $-0.063^{* * *}$ & $-0.067 * * *$ & $0.110^{* * *}$ & $0.091 * * *$ & 0.010 & 0.012 \\
\hline & $(0.020)$ & $(0.020)$ & $(0.032)$ & $(0.034)$ & $(0.009)$ & $(0.009)$ \\
\hline \multirow[t]{2}{*}{ Lending Risk } & -0.005 & -0.004 & 0.005 & 0.002 & 0.003 & 0.002 \\
\hline & $(0.003)$ & $(0.003)$ & $(0.009)$ & $(0.009)$ & $(0.002)$ & $(0.002)$ \\
\hline \multirow[t]{2}{*}{ Board Size } & $-0.003^{* *}$ & $-0.003^{* *}$ & $-0.006^{*}$ & -0.006 & $0.002^{* *}$ & $0.002^{* *}$ \\
\hline & $(0.001)$ & $(0.001)$ & $(0.003)$ & $(0.004)$ & $(0.001)$ & $(0.001)$ \\
\hline \multirow[t]{2}{*}{ Corruption } & -0.000 & -0.000 & -0.000 & -0.000 & $0.000^{* *}$ & $0.000 * * *$ \\
\hline & $(0.000)$ & $(0.000)$ & $(0.000)$ & $(0.000)$ & $(0.000)$ & $(0.000)$ \\
\hline \multirow[t]{2}{*}{ Supervisory Strength } & 0.000 & 0.000 & -0.001 & -0.001 & 0.000 & 0.000 \\
\hline & $(0.000)$ & $(0.000)$ & $(0.000)$ & $(0.000)$ & $(0.000)$ & $(0.000)$ \\
\hline \multirow[t]{2}{*}{ No Basel I } & 0.001 & 0.001 & 0.000 & -0.000 & $-0.001 * * *$ & $-0.001 * * *$ \\
\hline & $(0.001)$ & $(0.001)$ & $(0.001)$ & $(0.001)$ & $(0.000)$ & $(0.000)$ \\
\hline \multirow[t]{2}{*}{ Concentration } & $-0.004 * * *$ & $-0.004 * *$ & -0.000 & 0.002 & $0.003^{* * *}$ & $0.003^{* * *}$ \\
\hline & $(0.001)$ & $(0.001)$ & $(0.003)$ & $(0.003)$ & $(0.001)$ & $(0.001)$ \\
\hline \multirow[t]{2}{*}{ GDP Growth } & $0.045^{* * *}$ & $0.045^{* * *}$ & 0.018 & 0.014 & $-0.016^{* * *}$ & $-0.015^{* * *}$ \\
\hline & $(0.010)$ & $(0.010)$ & $(0.022)$ & $(0.023)$ & $(0.005)$ & $(0.005)$ \\
\hline \multirow[t]{2}{*}{ Econ_Dev } & $0.014^{* * *}$ & $0.015^{* * *}$ & $0.029 *$ & $0.046^{* * *}$ & $0.003^{* *}$ & 0.003 \\
\hline & $(0.003)$ & $(0.003)$ & $(0.015)$ & $(0.010)$ & $(0.002)$ & $(0.002)$ \\
\hline Public Debt & $0.006^{* * *}$ & $0.006^{* *}$ & -0.001 & 0.005 & 0.000 & -0.001 \\
\hline & $(0.002)$ & $(0.002)$ & $(0.006)$ & $(0.005)$ & $(0.001)$ & $(0.001)$ \\
\hline Shareholder Protection & 0.001 & $0.002^{* *}$ & $0.004^{* * *}$ & $0.004^{* *}$ & -0.000 & -0.000 \\
\hline & $(0.001)$ & $(0.001)$ & $(0.002)$ & $(0.002)$ & $(0.001)$ & $(0.001)$ \\
\hline Market Volatility & $-0.149 * * *$ & $-0.200^{* * *}$ & -0.065 & 0.068 & 0.037 & -0.027 \\
\hline & $(0.055)$ & $(0.056)$ & $(0.124)$ & $(0.119)$ & $(0.041)$ & $(0.039)$ \\
\hline CEO Power & & 0.000 & & -0.001 & & 0.000 \\
\hline & & $(0.000)$ & & $(0.001)$ & & $(0.000)$ \\
\hline Institutional Shareholders & & 0.002 & & -0.008 & & -0.000 \\
\hline & & $(0.002)$ & & $(0.005)$ & & $(0.001)$ \\
\hline Constant & $-0.118^{* * *}$ & $-0.124 * * *$ & -0.139 & $-0.256^{* * *}$ & -0.017 & -0.012 \\
\hline & $(0.028)$ & $(0.029)$ & $(0.129)$ & $(0.092)$ & $(0.013)$ & $(0.017)$ \\
\hline Observations & 2,305 & 2,204 & 2,305 & 2,204 & 2,305 & 2,204 \\
\hline Adjusted R-Squared & 0.299 & 0.309 & 0.192 & 0.199 & 0.079 & 0.077 \\
\hline Firm Fixed Effects & Yes & Yes & Yes & Yes & Yes & Yes \\
\hline Time Dummies & Yes & Yes & Yes & Yes & Yes & Yes \\
\hline
\end{tabular}




\section{Appendix: The Estimation of IPP}

IPP is the fair value of the deposit insurance premium (namely, the value that would be appropriate to pay to the deposit insurance fund) and increases with bank leverage and portfolio risk. IPP assumes the form of a put option written on bank assets and, when expressed as a per unit of insured debt, can be formulated as follows:

$$
I P P_{i, t}=N\left(y+\sigma_{A, t} \sqrt{T}\right)-(1-\delta) \frac{V_{A, t}}{L_{t}} N(y)
$$

where $y=\frac{\ln \left[L_{t} / V_{A, t}(1-\delta)\right]-\sigma_{A, t}^{2} T / 2}{\sigma_{A, t}}, \mathrm{~L}$ is the volume of bank total liabilities, $\mathrm{V}_{\mathrm{A}, \mathrm{t}}$ is the market value of bank total assets, $\sigma_{A, t}$ is the volatility of bank asset returns, and $\delta$ is the dividend payout ratio, defined as the ratio between dividend paid and the market value of bank assets.

The computation of IPP requires the estimation of two unobservables, the volatility of bank asset returns and the market value of bank assets. To measure bank asset return volatility and the market value of bank assets, we follow Flannery and Sorescu (1996), Ronn and Verma (1986), and Vallascas and Hagendorff (2013). Specifically, we use option pricing to derive a bank's asset return volatility and the market value of assets from the market value of equity and the volatility of equity returns. As in Vallascas and Hagendorff (2013) and Vassalou and Xing (2004), we infer the volatility of bank asset returns $\left(\sigma_{A, t}\right)$ and the market value of bank assets $\left(V_{A, t}\right)$ using an iterative process based on the Black-Scholes-Merton pricing model. We express the market value of a bank's equity $\left(V_{E, t}\right)$ as a function of the (unobservable) market value of assets $\left(\mathrm{V}_{\mathrm{A}, \mathrm{t}}\right)$ and derive asset value and the volatility of asset returns by solving the following system of nonlinear equations:

$$
\begin{array}{r}
V_{E, t}=V_{A, t} N\left(d_{1, t}\right)-L_{t} e^{-r_{f} T} N\left(d_{2, t}\right) \\
\sigma_{E, t}=\left(\frac{V_{A, t}}{V_{E, t}}\right) N\left(d_{1, t}\right) \sigma_{A, t}
\end{array}
$$

Equation (2.A) defines $\mathrm{V}_{\mathrm{E}, \mathrm{t}}$ as a call option on the market value of the bank's total assets, with $d_{1, t}=\frac{\ln \left(V_{A, t} / L_{t}\right)+\left(r_{f_{t}}+0.5 \sigma_{A, t}\right) T}{\sigma_{A, t}}$ and $d_{2, t}=d_{1, t}-\sigma_{A, t} T$. Equation $(3 \mathrm{~A})$ is the optimal hedge equation that relates the 
volatility of bank equity returns to the volatility of total asset returns (both expressed on an annualized basis). To solve this system of equations and to extract $\sigma_{A, t}$ for each bank at yearly intervals, we employ as starting values for $\sigma_{A, t}$ the historical annualized yearly volatility of equity returns multiplied by the ratio of the market value of equity to the sum of the market value of equity and the book value of total liabilities, i.e. $\sigma_{A, t}=\sigma_{E, t} V_{E, t} /\left(V_{E, t}+L_{t}\right)$. Finally, a Newton search algorithm identifies the yearly values for $\mathrm{V}_{\mathrm{A}, \mathrm{t}}$ and $\sigma_{A, t}$ in an iterative process. 


\section{Online Appendix}

Table A1: Alternative Specifications

\begin{tabular}{|c|c|c|c|c|}
\hline \multicolumn{5}{|c|}{$\begin{array}{l}\text { This Table shows the results of additional tests on the impact of board independence on bank risk. Panel A reports the results of random effect models } \\
\text { while Panel B employs two lags of the bank-level explanatory variables in the fixed effect regressions. Panel C shows the results of dynamic panel data } \\
\text { models estimated via the two-step GMM estimator proposed by Blundell and Bond (1998) with standard errors adjusted via the finite sample } \\
\text { correction derived by Windmeijer (2005). Panel D refers to a 2SLS analysis based on a panel data setting and with contemporaneous explanatory } \\
\text { variables. The degree of board independence is instrumented using the log transformation of the ratio between newspapers in circulation and population } \\
\text { in a country and the median value of the degree of board independence in country with the same legal origin and banking system size. Board } \\
\text { Independence is the ratio between the number of independent directors and the total number of directors, Post } 2009 \text { is a dummy equal to one for the } \\
\text { years following } 2009 \text {. All specifications control for the explanatory variables employed in the main tests including time dummies. }{ }^{* * *}(* *, *) \text { indicates } \\
\text { significance at the } 1(5,10) \text { percent level. }\end{array}$} \\
\hline & (1) & (2) & (3) & (4) \\
\hline \multicolumn{5}{|l|}{ Panel A: Random Effect Model } \\
\hline & Ln (Z_Score) & Equity Volatility & VaR & ES \\
\hline \multirow[t]{2}{*}{ Board Independence } & $0.202 *$ & 0.001 & 0.001 & 0.002 \\
\hline & $(0.106)$ & $(0.002)$ & $(0.002)$ & $(0.004)$ \\
\hline \multirow[t]{2}{*}{ Board Independence* Post 2009} & $-0.220 * *$ & $-0.004 * * *$ & $-0.006^{* * *}$ & $-0.011 * * *$ \\
\hline & $(0.093)$ & $(0.002)$ & $(0.002)$ & $(0.004)$ \\
\hline \multirow[t]{2}{*}{ Post 2009} & 0.019 & 0.001 & 0.002 & 0.004 \\
\hline & $(0.093)$ & $(0.002)$ & $(0.003)$ & $(0.004)$ \\
\hline \multicolumn{5}{|l|}{ Adjusted R-Squared } \\
\hline Bank Controls & Yes & Yes & Yes & Yes \\
\hline Country Controls & Yes & Yes & Yes & Yes \\
\hline Bank Fixed Effects & No & No & No & No \\
\hline Country Fixed Effects & Yes & Yes & Yes & No \\
\hline Time Dummies & Yes & Yes & Yes & Yes \\
\hline \multicolumn{5}{|c|}{ Panel B: Fixed Effect Models - Two Lags } \\
\hline & Ln (Z_Score) & Equity Volatility & VaR & ES \\
\hline \multirow[t]{2}{*}{ Board Independence } & 0.118 & 0.003 & 0.003 & 0.005 \\
\hline & $(0.177)$ & $(0.003)$ & $(0.004)$ & $(0.006)$ \\
\hline \multirow[t]{2}{*}{ Board Independence* Post 2009} & $-0.221 * *$ & $-0.008^{* * *}$ & $-0.010^{* * *}$ & $-0.018^{* * *}$ \\
\hline & $(0.102)$ & $(0.002)$ & $(0.002)$ & $(0.004)$ \\
\hline \multirow[t]{2}{*}{ Post $_{2009}$} & $-0.199 *$ & -0.001 & -0.003 & -0.003 \\
\hline & $(0.109)$ & $(0.003)$ & $(0.003)$ & $(0.005)$ \\
\hline Observations & 1,953 & 1,956 & 1,956 & 1,956 \\
\hline Adjusted R-Squared & 0.061 & 0.662 & 0.696 & 0.669 \\
\hline Bank Controls & Yes & Yes & Yes & Yes \\
\hline Country Controls & Yes & Yes & Yes & Yes \\
\hline Bank Fixed Effects & Yes & Yes & Yes & Yes \\
\hline Country Fixed Effects & No & No & No & No \\
\hline Time Dummies & Yes & Yes & Yes & Yes \\
\hline
\end{tabular}


Table A1 (continued)

\begin{tabular}{|c|c|c|c|c|}
\hline & $(1)$ & $(2)$ & (3) & $(4)$ \\
\hline \multicolumn{5}{|l|}{ Panel C: GMM Model } \\
\hline & Ln (Z_Score) & Equity Volatility & VaR & ES \\
\hline \multirow[t]{2}{*}{ Risk $t-1_{1}$} & $0.167^{* * *}$ & $0.348^{* * *}$ & $0.308^{* * *}$ & $0.264 * * *$ \\
\hline & $(0.041)$ & $(0.039)$ & $(0.036)$ & $(0.034)$ \\
\hline \multirow[t]{2}{*}{$\operatorname{Risk}_{t-2}$} & & $-0.127^{* * *}$ & $-0.060 *$ & \\
\hline & & $(0.037)$ & $(0.036)$ & \\
\hline \multirow[t]{2}{*}{ Board Independence } & $0.457 * * *$ & $0.005^{*}$ & 0.001 & 0.010 \\
\hline & $(0.164)$ & $(0.003)$ & $(0.004)$ & $(0.007)$ \\
\hline \multirow[t]{2}{*}{ Board Independence* Post 2009} & $-0.198 *$ & $-0.007^{* * *}$ & $-0.008^{* * *}$ & $-0.015^{* * *}$ \\
\hline & $(0.113)$ & $(0.002)$ & $(0.003)$ & $(0.004)$ \\
\hline \multirow[t]{2}{*}{ Post $_{2009}$} & 0.034 & 0.002 & 0.002 & 0.001 \\
\hline & $(0.092)$ & $(0.002)$ & $(0.002)$ & $(0.004)$ \\
\hline Observations & 2,204 & 1,970 & 1,970 & 2,207 \\
\hline M2-test (p-value) & 0.216 & 0.555 & 0.106 & 0.141 \\
\hline Hansen J test ( $\mathrm{p}$-value) & 0.825 & 0.773 & 0.709 & 0.661 \\
\hline Bank Controls & Yes & Yes & Yes & Yes \\
\hline Country Controls & Yes & Yes & Yes & Yes \\
\hline Country Fixed Effects & Yes & Yes & Yes & Yes \\
\hline Time Dummies & Yes & Yes & Yes & Yes \\
\hline
\end{tabular}

\begin{tabular}{|c|c|c|c|c|}
\hline \multicolumn{5}{|l|}{ Panel D: Instrumental Variable Analysis } \\
\hline & Ln (Z_Score) & Equity Volatility & VaR & ES \\
\hline Board Independence & $\begin{array}{l}-0.565 \\
(0.943)\end{array}$ & $\begin{array}{c}0.032 \\
(0.027)\end{array}$ & $\begin{array}{c}0.059 \\
(0.037)\end{array}$ & $\begin{array}{c}0.090 \\
(0.060)\end{array}$ \\
\hline Board Independence* Post2009 & $\begin{array}{l}-0.205 \\
(0.140)\end{array}$ & $\begin{array}{c}-0.011 * * * \\
(0.004)\end{array}$ & $\begin{array}{c}-0.013 * * * \\
(0.005)\end{array}$ & $\begin{array}{c}-0.024 * * * \\
(0.008)\end{array}$ \\
\hline Post 2009 & $\begin{array}{c}-0.332^{* *} \\
(0.133)\end{array}$ & $\begin{array}{c}0.006^{* *} \\
(0.003)\end{array}$ & $\begin{array}{l}0.006 \\
(0.004)\end{array}$ & $\begin{array}{l}0.010 \\
(0.006)\end{array}$ \\
\hline Observations & 2,215 & 2,215 & 2,215 & 2,215 \\
\hline Adjusted R-Squared & -0.057 & 0.653 & 0.669 & 0.632 \\
\hline $\begin{array}{l}\text { Kleibergen_Paap Underidentification test } \\
(p=\text { value })\end{array}$ & 0.026 & 0.026 & 0.026 & 0.026 \\
\hline Hansen J test ( $\mathrm{p}$-value & 0.207 & 0.550 & 0.339 & 0.599 \\
\hline Bank Controls & Yes & Yes & Yes & Yes \\
\hline Country Controls & Yes & Yes & Yes & Yes \\
\hline Bank Fixed Effects & Yes & Yes & Yes & Yes \\
\hline Country Fixed Effects & No & No & No & No \\
\hline Time Dummies & Yes & Yes & Yes & Yes \\
\hline
\end{tabular}


Table A2: Sub-Sample Analysis for Bailout and Non-Bailout Banks

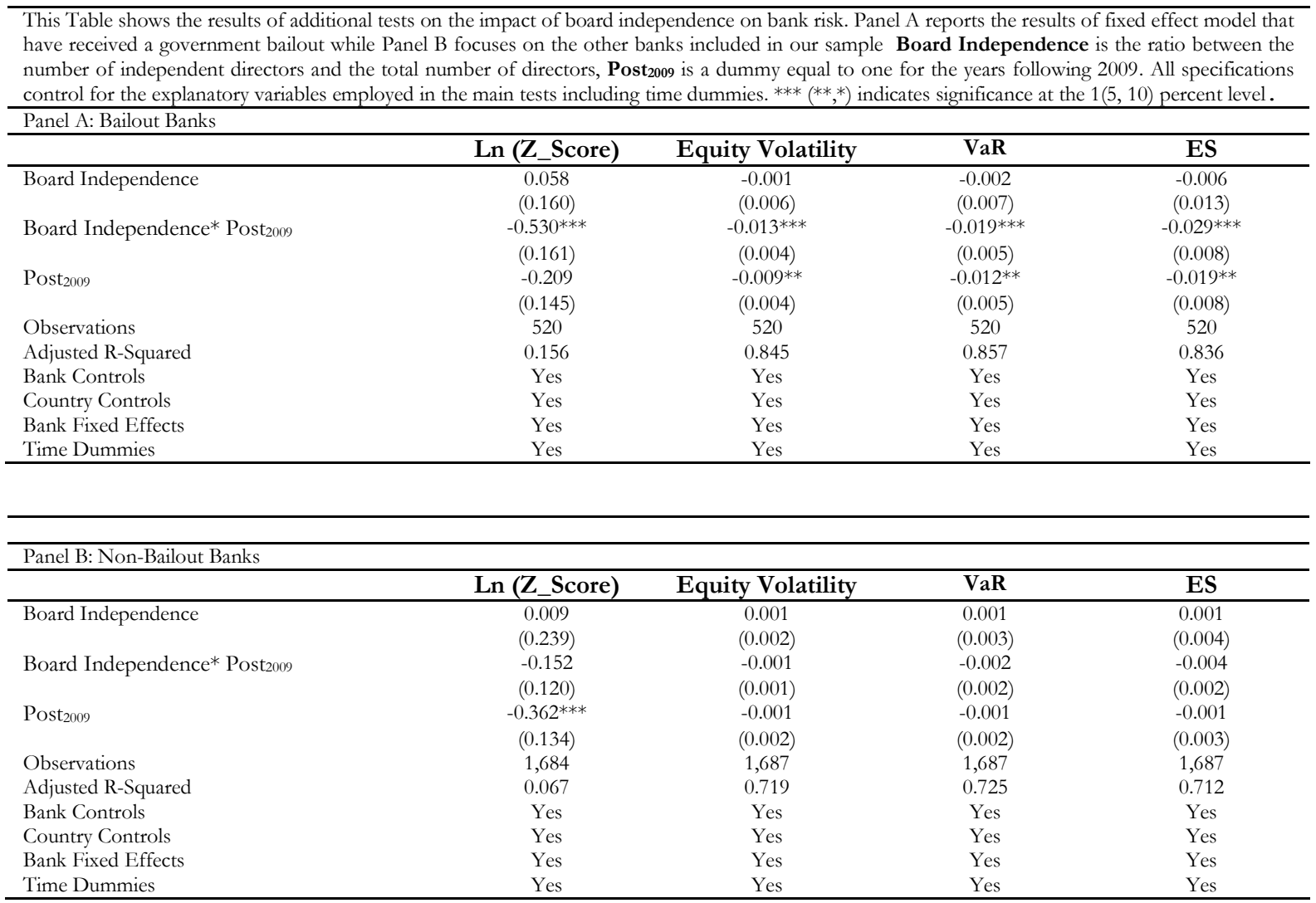


Table A3: US Sample- Risk Analysis

\begin{tabular}{|c|c|c|c|c|}
\hline \multicolumn{5}{|c|}{$\begin{array}{l}\text { This Table shows the results of the tests on the impact of board independence on bank risk for the sub-sample of US banks. Panel A reports the results } \\
\text { of the fixed effect model for the sub-sample of US banks while Panel B focuses on US banks that have received a government support and Panel C on } \\
\text { the other banks included in our sample. Board Independence is the ratio between the number of independent directors and the total number of } \\
\text { directors, Post } 2009 \text { Bailout is a dummy equal to one for the years following } 2009 \text { for banks that received a government bailout, Post } 2009 \_N o \text { Bailout is a } \\
\text { dummy equal to one for the years following } 2009 \text { for the remaining banks in the sample, Post } 2009 \text { is a dummy equal to one for the years following } 2009 \text {. } \\
\text { All specifications control for the explanatory variables employed in the main tests including time dummies. }{ }^{* * *}(* *, *) \text { indicates significance at the } 1(5,10) \\
\text { percent level. }\end{array}$} \\
\hline \multicolumn{5}{|c|}{ Panel A: All US Banks } \\
\hline & Ln (Z_Score) & Equity Volatility & VaR & ES \\
\hline Board Independence & $\begin{array}{l}-0.175 \\
(0.392)\end{array}$ & $\begin{array}{c}0.003 \\
(0.005)\end{array}$ & $\begin{array}{c}0.003 \\
(0.007)\end{array}$ & $\begin{array}{c}0.002 \\
(0.012)\end{array}$ \\
\hline Board Independence*Post2009_Bailout & $\begin{array}{c}-0.582 \\
(0.510)\end{array}$ & $\begin{array}{c}-0.018^{* * *} \\
(0.005)\end{array}$ & $\begin{array}{c}-0.019 * * * \\
(0.007)\end{array}$ & $\begin{array}{c}-0.038^{* * *} \\
(0.011)\end{array}$ \\
\hline Board Independence*Post2009_No_Bailout & $\begin{array}{l}-0.360 \\
(0.399)\end{array}$ & $\begin{array}{l}-0.009 \\
(0.008)\end{array}$ & $\begin{array}{l}-0.013 \\
(0.013)\end{array}$ & $\begin{array}{l}-0.024 \\
(0.018)\end{array}$ \\
\hline Post2009_Bailouts & $\begin{array}{l}-0.193 \\
(0.236)\end{array}$ & $\begin{array}{c}-0.047 * * * \\
(0.003)\end{array}$ & $\begin{array}{c}-0.068^{* * *} \\
(0.004)\end{array}$ & $\begin{array}{c}-0.100 * * * \\
(0.007)\end{array}$ \\
\hline Post2009_No_Bailout & $\begin{array}{c}-0.362^{*} \\
(0.199)\end{array}$ & $\begin{array}{c}-0.045^{* * *} \\
(0.004)\end{array}$ & $\begin{array}{c}-0.064^{* * *} \\
(0.005)\end{array}$ & $\begin{array}{c}-0.093 * * * \\
(0.008)\end{array}$ \\
\hline Observations & 359 & 359 & 359 & 359 \\
\hline Adjusted R-Squared & 0.174 & 0.886 & 0.881 & 0.862 \\
\hline Bank Controls & Yes & Yes & Yes & Yes \\
\hline Country Controls & Yes & Yes & Yes & Yes \\
\hline Bank Fixed Effects & Yes & Yes & Yes & Yes \\
\hline Time Dummies & Yes & Yes & Yes & Yes \\
\hline
\end{tabular}

\begin{tabular}{|c|c|c|c|c|}
\hline \multicolumn{5}{|l|}{ Panel B: Bailout US Banks } \\
\hline & Ln (Z_Score) & Equity Volatility & VaR & ES \\
\hline Board Independence & $\begin{array}{l}-0.569 \\
(0.395)\end{array}$ & $\begin{array}{c}0.000 \\
(0.006)\end{array}$ & $\begin{array}{c}0.000 \\
(0.007)\end{array}$ & $\begin{array}{c}0.000 \\
(0.012)\end{array}$ \\
\hline Board Independence* Post2009 & $\begin{array}{l}-0.433 \\
(0.496)\end{array}$ & $\begin{array}{c}-0.019 * * * \\
(0.005)\end{array}$ & $\begin{array}{c}-0.021 * * * \\
(0.007)\end{array}$ & $\begin{array}{c}-0.044 * * * \\
(0.011)\end{array}$ \\
\hline Post $_{2009}$ & $\begin{array}{l}-0.283 \\
(0.251)\end{array}$ & $\begin{array}{c}-0.049 * * * \\
(0.004)\end{array}$ & $\begin{array}{c}-0.069 * * * \\
(0.005)\end{array}$ & $\begin{array}{c}-0.100 * * * \\
(0.009)\end{array}$ \\
\hline Observations & 253 & 253 & 253 & 253 \\
\hline Adjusted R-Squared & 0.220 & 0.918 & 0.915 & 0.903 \\
\hline Bank Controls & Yes & Yes & Yes & Yes \\
\hline Country Controls & Yes & Yes & Yes & Yes \\
\hline Bank Fixed Effects & Yes & Yes & Yes & Yes \\
\hline Time Dummies & Yes & Yes & Yes & Yes \\
\hline
\end{tabular}

\begin{tabular}{|c|c|c|c|c|}
\hline \multicolumn{5}{|l|}{ Panel C: Non-Bailout US Banks } \\
\hline & Ln (Z_Score) & Equity Volatility & VaR & ES \\
\hline \multirow[t]{2}{*}{ Board Independence } & 1.115 & -0.006 & -0.005 & -0.042 \\
\hline & $(1.162)$ & $(0.009)$ & $(0.018)$ & $(0.034)$ \\
\hline \multirow[t]{2}{*}{ Board Independence* Post 2009} & -0.460 & -0.006 & -0.009 & -0.013 \\
\hline & $(0.344)$ & $(0.007)$ & $(0.014)$ & $(0.017)$ \\
\hline \multirow[t]{2}{*}{ Post 2009} & 0.174 & 0.003 & 0.010 & 0.008 \\
\hline & $(0.389)$ & $(0.007)$ & $(0.012)$ & $(0.020)$ \\
\hline Observations & 106 & 106 & 106 & 106 \\
\hline Adjusted R-Squared & 0.101 & 0.813 & 0.778 & 0.744 \\
\hline Bank Controls & Yes & Yes & Yes & Yes \\
\hline Country Controls & Yes & Yes & Yes & Yes \\
\hline Bank Fixed Effects & Yes & Yes & Yes & Yes \\
\hline Time Dummies & Yes & Yes & Yes & Yes \\
\hline
\end{tabular}


Table A4: US Sample- Z-Score Components

This Table shows the results of the impact of board independence on Z-Score components for the sub-sample of US banks. Board Independence is the ratio between the number of independent directors and the total number of directors, Post 2009_Bailout is a dummy equal to one for the years following 2009 for banks that received a government bailout, Post2009 No Bailout is a dummy equal to one for the years following 2009 for the remaining banks in the sample. All specifications control for the explanatory variables employed in the main tests including time dummies. ${ }^{* * *}(* *, *)$ indicates significance at the $1(5,10)$ percent level.

\begin{tabular}{|c|c|c|c|}
\hline & ROA & Equity Ratio & ROA Volatility \\
\hline \multirow[t]{2}{*}{ Board Independence } & $-0.010^{* *}$ & 0.005 & -0.003 \\
\hline & $(0.004)$ & $(0.015)$ & $(0.004)$ \\
\hline \multirow[t]{2}{*}{ Board Independence*Post2009_Bailout } & 0.006 & -0.044 & $-0.008^{*}$ \\
\hline & $(0.009)$ & $(0.029)$ & $(0.004)$ \\
\hline \multirow[t]{2}{*}{ Board Independence*Post2009_No_Bailout } & -0.003 & -0.005 & -0.003 \\
\hline & $(0.005)$ & $(0.017)$ & $(0.003)$ \\
\hline \multirow[t]{2}{*}{ Post2009_Bailouts } & $0.010^{* *}$ & $0.024 *$ & $-0.005^{* *}$ \\
\hline & $(0.004)$ & $(0.012)$ & $(0.002)$ \\
\hline \multirow{2}{*}{ Post2009_No_Bailout } & $0.008^{* * *}$ & 0.006 & $-0.005^{* *}$ \\
\hline & $(0.003)$ & $(0.007)$ & $(0.002)$ \\
\hline Observations & 359 & 359 & 359 \\
\hline Adjusted R-Squared & 0.409 & 0.321 & 0.192 \\
\hline Bank Controls & Yes & Yes & Yes \\
\hline Country Controls & Yes & Yes & Yes \\
\hline Bank Fixed Effects & Yes & Yes & Yes \\
\hline Time Dummies & Yes & Yes & Yes \\
\hline
\end{tabular}

